\title{
Operation Ajax: A Case Study on Analyst-Policy Maker Tensions and the Challenges of Estimative Intelligence
}

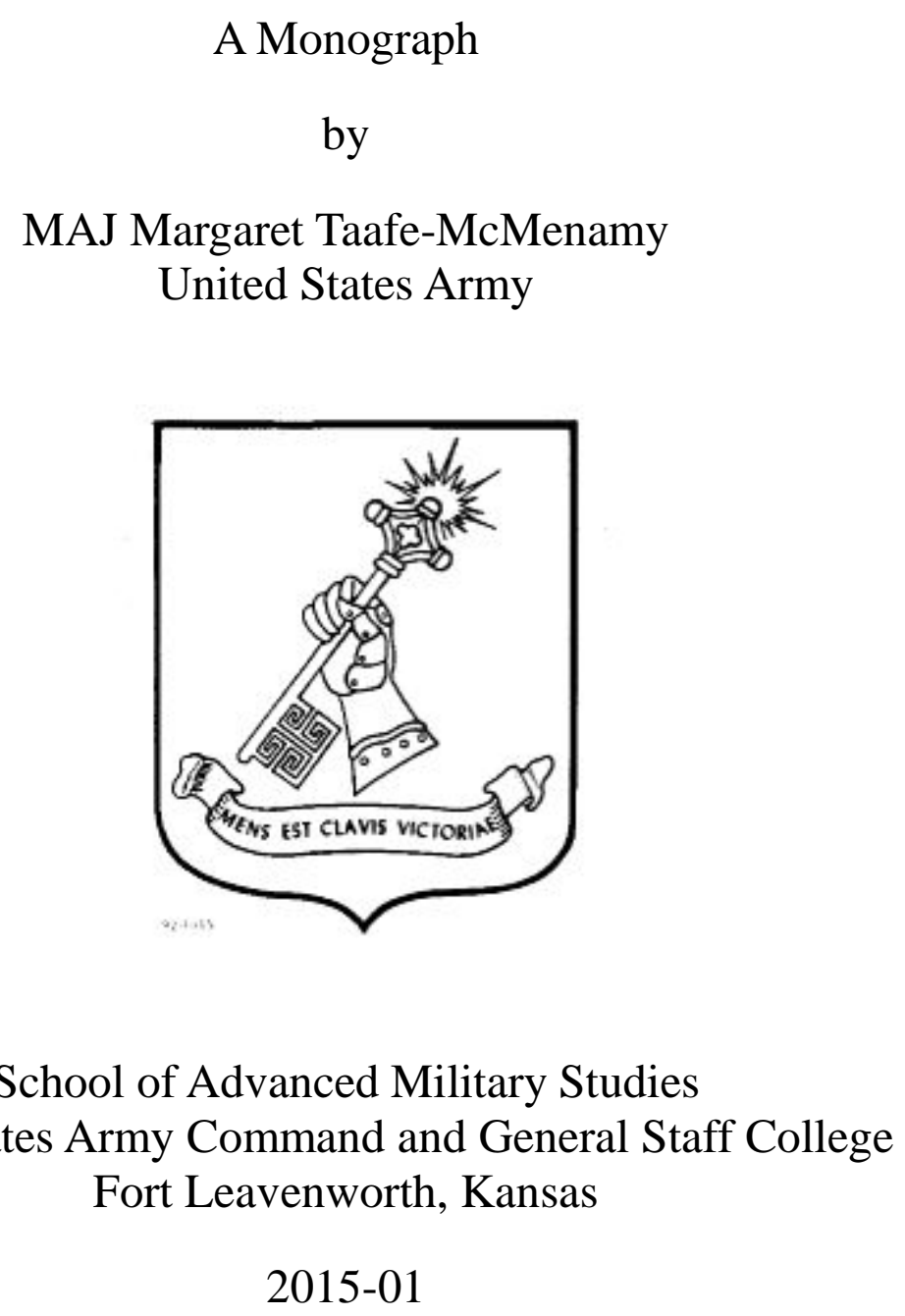

2015-01

Approved for public release; distribution is unlimited. 


\begin{tabular}{|c|c|c|c|c|c|c|}
\hline \multicolumn{6}{|c|}{ REPORT DOCUMENTATION PAGE } & $\begin{array}{l}\text { Form Approved } \\
\text { OMB No. 0704-0188 }\end{array}$ \\
\hline \multicolumn{7}{|c|}{ 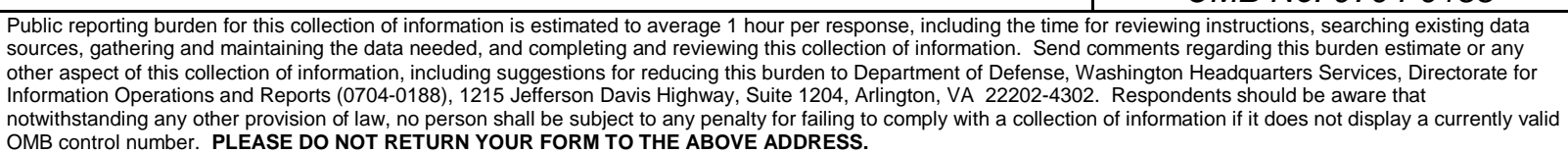 } \\
\hline \multicolumn{3}{|c|}{$\begin{array}{l}\text { 1. REPORT DATE (DD-MM-YYYY) } \\
\text { 21-05-2015 }\end{array}$} & \multicolumn{3}{|c|}{$\begin{array}{l}\text { 2. REPORT TYPE } \\
\text { Monograph }\end{array}$} & \begin{tabular}{l|l} 
3. DATES COVERED (From - To) \\
JUN 2014 - MAY 2015
\end{tabular} \\
\hline \multirow{2}{*}{\multicolumn{6}{|c|}{$\begin{array}{l}\text { 4. TITLE AND SUBTITLE } \\
\text { Operation Ajax: A Case Study on Analyst-Policymaker Tensions and the } \\
\text { Challenges of Estimative Intelligence }\end{array}$}} & 5a. CONTRACT NUMBER \\
\hline & & & & & & 5b. GRANT NUMBER \\
\hline & 5c. PROGRAM ELEMENT NUMBER \\
\hline \multirow{3}{*}{\multicolumn{6}{|c|}{$\begin{array}{l}\text { 6. AUTHOR(S) } \\
\text { MAJ Margaret Taafe-McMenamy }\end{array}$}} & 5d. PROJECT NUMBER \\
\hline & & & & & & 5e. TASK NUMBER \\
\hline & & & & & & 5f. WORK UNIT NUMBER \\
\hline \multicolumn{6}{|c|}{$\begin{array}{l}\text { 7. PERFORMING ORGANIZATION NAME(S) AND ADDRESS(ES) } \\
\text { U.S. Army Command and General Staff College } \\
\text { ATTN: ATZL-SWD-GD } \\
\text { Fort Leavenworth, KS } 66027-2301\end{array}$} & $\begin{array}{l}\text { 8. PERFORMING ORG REPORT } \\
\text { NUMBER }\end{array}$ \\
\hline \multirow{2}{*}{\multicolumn{6}{|c|}{$\begin{array}{l}\text { 9. SPONSORING / MONITORING AGENCY NAME(S) AND ADDRESS(ES) } \\
\text { Advanced Military Studies Program. }\end{array}$}} & $\begin{array}{l}\text { 10. SPONSOR/MONITOR'S } \\
\text { ACRONYM(S) }\end{array}$ \\
\hline & & & & & & $\begin{array}{l}\text { 11. SPONSOR/MONITOR'S REPORT } \\
\text { NUMBER(S) }\end{array}$ \\
\hline \multicolumn{7}{|c|}{$\begin{array}{l}\text { 12. DISTRIBUTION / AVAILABILITY STATEMENT } \\
\text { Approved for Public Release; Distribution is Unlimited }\end{array}$} \\
\hline \multicolumn{7}{|c|}{ 13. SUPPLEMENTARY NOTES } \\
\hline \multicolumn{7}{|c|}{$\begin{array}{l}\text { 14. ABSTRACT } \\
\text { This monograph analyzes Operation Ajax as a historical case study of the inherent challenges of } \\
\text { estimative intelligence and analyst-policymaker tensions. In 1953, the Central Intelligence Agency (CIA) led a } \\
\text { coup that overthrew Iran's elected prime minister, Dr. Mohammed Mosaddeq. The coup, titled Operation Ajax, } \\
\text { coincided with the early Cold War years and the development of the nascent interagency intelligence } \\
\text { community. Historians frequently study Operation Ajax as an example of the U.S. government's early attempts to } \\
\text { employ covert action as a foreign policy tool. A less studied aspect of the coup is the intelligence estimates that } \\
\text { informed and influenced the Truman and Eisenhower administrations' policy decisions during the Anglo-Iranian } \\
\text { Oil Crisis. A careful analysis of the Iranian estimates produced by the Office of National Estimates (ONE) } \\
\text { between } 1950 \text { and } 1953 \text { reveals that ONE effectively informed and influenced the Truman administration, but that } \\
\text { influence was lost during the Eisenhower administration. Structural and organizational impediments within the } \\
\text { CIA, coupled with flawed processes and procedures introduced by the Dulles brothers, mitigated efforts by leading } \\
\text { CIA analysts to coordinate intelligence analysis, remove bias, and accurately inform and influence policymakers. }\end{array}$} \\
\hline \multicolumn{7}{|c|}{$\begin{array}{l}\text { 15. SUBJECT TERMS } \\
\text { Intelligence Estimates; Operation Ajax; Central Intelligence Agency; Covert Operations; Department of State; } \\
\text { Truman Administration; Eisenhower Administration; Sherman Kent }\end{array}$} \\
\hline \multicolumn{4}{|c|}{ 16. SECURITY CLASSIFICATION OF: } & \multirow{2}{*}{$\begin{array}{l}\text { 17. LIMITATION } \\
\text { OF ABSTRACT } \\
\text { (U) }\end{array}$} & \multirow{2}{*}{$\begin{array}{l}\text { 18. NUMBER } \\
\text { OF PAGES } \\
\quad 65\end{array}$} & $\begin{array}{l}\text { 19a. NAME OF RESPONSIBLE PERSON } \\
\text { MAJ Margaret Taafe-McMenamy }\end{array}$ \\
\hline $\begin{array}{l}\text { a. REPORT } \\
\text { (U) }\end{array}$ & $\begin{array}{l}\text { b. ABSTRACT } \\
\text { (U) }\end{array}$ & c. TH & $\begin{array}{l}\text { IS PAGE } \\
\text { (U) }\end{array}$ & & & $\begin{array}{l}\text { 19b. PHONE NUMBER (include area code) } \\
\text { (702) } 340-1580\end{array}$ \\
\hline
\end{tabular}




\section{Monograph Approval}

Name of

Candidate:

Monograph Title: Operation Ajax: A Case-Study on Analyst-Policymaker Tensions and the Challenges of Estimative Intelligence

Approved by:

Robert T. Davis II, Ph.D. , Monograph Director

Craig Berryman, COL, FA , Seminar Leader

Henry A. Arnold III, COL, IN

, Director, School of Advanced Military Studies

Accepted this $21^{\text {st }}$ day of May 2015 by:

Robert F. Baumann, Ph.D.

, Director, Graduate Degree Programs

The opinions and conclusions expressed herein are those of the student author, and do not necessarily represent the views of the US Army Command and General Staff College or any other government agency. (References to this study should include the foregoing statement.) 


\begin{abstract}
Operation Ajax: A Case-Study on Analyst-Policymaker Tensions and the Challenges of Estimative Intelligence, 65 pages.

This monograph analyzes Operation Ajax as a historical case study of the inherent challenges of estimative intelligence and analyst-policymaker tensions. In 1953, the Central Intelligence Agency (CIA) led a coup that overthrew Iran's elected prime minister, Dr. Mohammed Mossadeq. The coup, titled Operation Ajax, coincided with the early Cold War years and the development of the nascent interagency intelligence community. Historians frequently study Operation Ajax as an example of the US government's early attempts to employ covert action as a foreign policy tool. A less studied aspect of the coup is the intelligence estimates that informed and influenced the Truman and Eisenhower administrations' policy decisions during the Anglo-Iranian Oil Crisis. A careful analysis of the Iranian estimates produced by the Office of National Estimates (ONE) between 1950-1953 reveals that ONE effectively informed and influenced the Truman administration, but that influence was lost during the Eisenhower administration. Structural and organizational impediments within the CIA, coupled with flawed processes and procedures introduced by the Dulles brothers, mitigated efforts by leading CIA analysts to coordinate intelligence analysis, remove bias, and accurately inform and influence policymakers.
\end{abstract}




\section{Contents}

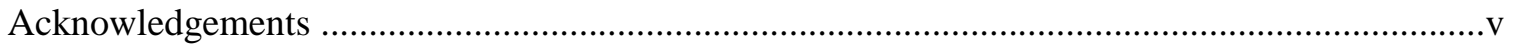

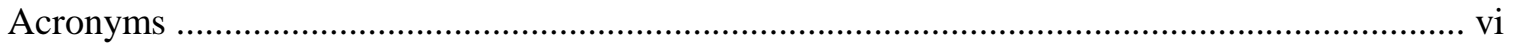

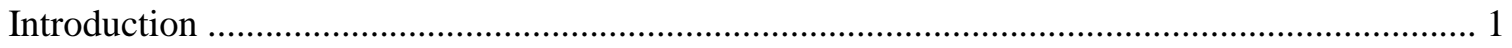

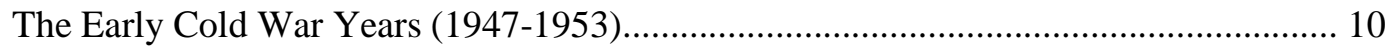

The Birth of the CIA and National Intelligence Estimating ........................................... 16

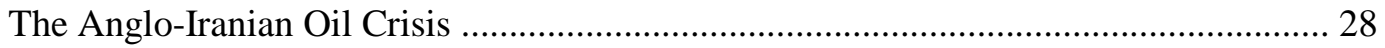

The Truman Administration’s Policy Toward Iran ........................................................ 32

The Eisenhower Administration’s Policy Toward Iran................................................. 47

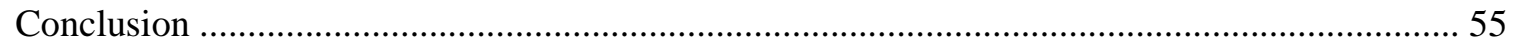

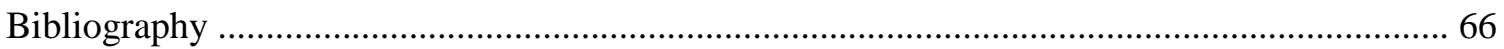




\section{Acknowledgements}

Special thanks to the faculty and staff of the School of Advanced Military Studies and the Command and General Staff College, particularly Dr. Robert Davis, Dr. John Breen and Mr.

Stephen Melton, without whom this monograph would not be possible. I would also like to thank Dr. David Robarge from the Central Intelligence Agency History Department, and the archivists

from the Harry S. Truman and Dwight D. Eisenhower Presidential Libraries, for their support and assistance. 


\section{Acronyms}

$\begin{array}{ll}\text { AIOC } & \text { Anglo-Iranian Oil Company } \\ \text { ARAMCO } & \text { Arabian-American Oil Company } \\ \text { CIA } & \text { Central Intelligence Agency } \\ \text { CIG } & \text { Central Intelligence Group } \\ \text { DDI } & \text { Deputy Director of Intelligence } \\ \text { FOIA } & \text { Freedom of Information Act } \\ \text { FRUS } & \text { Foreign Relations of the United States } \\ \text { INR } & \text { Bureau of Intelligence and Research } \\ \text { ISIL } & \text { Islamic State of Iraq and the Levant } \\ \text { JIC } & \text { Joint Intelligence Center } \\ \text { NIE } & \text { National Intelligence Estimates } \\ \text { NSC } & \text { National Security Council } \\ \text { ONE } & \text { Office of National Estimates } \\ \text { OSS } & \text { Office of Strategic Studies } \\ \text { R\&A } & \text { Research and Analysis } \\ \text { SAVAK } & \text { Iranian Organization of Intelligence and Secret Police } \\ \end{array}$




\section{Introduction}

What is lacking in the public debate is not information on strategic intelligence successes and failures but rigorous, scholarly, and systematic analyses that make sense of the body of evidence. What is especially lacking are examinations of what impact or influence strategic intelligence, or the paucity of strategic intelligence, had on presidential decision making.

—_Richard L. Russell, Sharpening Strategic Intelligence

In 1953, the Central Intelligence Agency (CIA), in conjunction with British and Iranian affiliates, led a coup in Iran that toppled the democratically elected Prime Minister, Dr. Mohammed Mosaddeq. ${ }^{1}$ The coup, which was codenamed Operation Ajax, is emblematic of the United States government's attempt to use covert action as part of a broader strategic policy to combat the spread of communism during the Cold War. ${ }^{2}$ After the coup, the United States government bolstered the Iranian monarch, Shah Mohammad Reza Pavlavi, who later consolidated his power in an authoritarian regime. Ultimately, as discontent mounted among numerous political, religious and social groups in Iran, a radical religious movement rose to power resulting in the Iranian Revolution of $1978 .{ }^{3}$ US relations with Iran remain strained in

${ }^{1}$ Due to variations in translations from Persian to English, multiple spellings of the former Iranian prime minister's name appear in primary source documents (to include Mossadegh and Mossadiq, to name a few). When using a direct quote, the prime minister's name will be spelled as it appeared in the original quotation. For consistency, in all other instances in this paper, his last name will be spelled "Mosaddeq."

${ }^{2}$ Kenneth A. Osgood's recent book is an excellent study of Eisenhower's broader approach to prosecuting the Cold War. Osgood argues that covert operations were one of several means employed in the conduct of psychological warfare to combat the spread of communism. See Kenneth Alan Osgood, Total Cold War (Lawrence, KS: University of Kansas, 2006).

${ }^{3}$ The debate regarding the causes of the 1953 coup and their contributions to the 1978 social revolution in Iran continues today. Due to a range of variables that spanned a twenty-five year period, a direct causal link between the 1953 coup that overthrew Mosaddeq and the rise of the Islamic theocracy in Iran cannot be drawn. Most historians agree that the coup hastened the demise of a democratically elected government and had a damaging effect on Iranian perceptions of the United States. It is debatable whether a liberal democratic ideology had actually gained a foothold in Iran in 1951-1953, or whether an anti-imperialist nationalist ideology was at the core of Mosaddeq's National Front movement. It is also unclear whether Mosaddeq's premiership would have survived internal Iranian political dissatisfaction (pervasive among prominent clerics, bazaaris and monarchists at the time) and historic factionalism in the absence of a US-sponsored 
2015, thirty-six years after the United States severed diplomatic ties with Iran following the nearly two-year long Iranian hostage crisis.

Unlike the Cuban Missile Crisis, the Iranian Revolution, and the terrorist attacks of September 11, 2001, Operation Ajax is not commonly referred to as an example of an intelligence failure, largely because it did not involve strategic surprise. ${ }^{4}$ Historians continue to debate the merits of the operation and whether it was a clandestine success or failure. As Richard Russell argued in Sharpening Strategic Intelligence, "the CIA's covert action that returned the Shah of Iran to power is still heralded as a high water mark for the agency's myth of covert action capabilities." ${ }^{5}$ Others, such as historian Shiva Balaghi, have referred to the coup as a representation of the "height of US imperial folly." ${ }^{6}$ Operation Ajax is controversial because of its unintended consequences that call into question the effectiveness, utility, and morality of the use of covert action. As such, the United States' role in the coup has been central to the historical narrative that has framed relations between the two countries since the Iranian Revolution in 1978. ${ }^{7}$ Kermit Roosevelt, the lead CIA operative in charge of Operation Ajax, published his

coup. It is generally accepted that US support for the Shah, to include financial aid, weapons sales, and the training of the SAVAK (secret police) facilitated the Shah's centralization of power in the decades following the coup, but it is not clear to what extent US involvement inadvertently influenced the Iranian Revolution. For more on the political and intellectual trends of Iranian society in 1951-1953, see James A. Bill and William Roger Louis, Mussadiq, Iranian Nationalism, and Oil (Austin, TX: University of Texas Press, 1988). For more on the origins of social revolution in Iran, see Misagh Parsa, States, Ideologies, and Social Revolutions (Cambridge, UK: Cambridge University Press, 2000); Nikki R. Keddie, Modern Iran (New Haven, CT: Yale University Press, 2003); and Ervand Abrahamian, A History of Modern Iran (Cambridge, UK: Cambridge University Press, 2008).

${ }^{4}$ For more on these oft-cited examples of "intelligence failures," see Richard L. Russell, Sharpening Strategic Intelligence: Why the CIA Gets It Wrong, and What Needs to Be Done to Get It Right (New York, NY: Cambridge University Press, 2007).

${ }^{5}$ Ibid., 10.

${ }^{6}$ Shiva Balaghi, "Silenced Histories And Sanitized Autobiographies: The 1953 CIA Coup In Iran,” Biography 36, no. 1 (Winter 2013): 79.

${ }^{7}$ For an example of the ongoing debate, see Ray Takeyh, "What Really Happened in Iran: The CIA, the Ouster of Mosaddeq, and the Restoration of the Shah,” Foreign Affairs (July/ August 2014), 2-12; Christopher Debellaigue, “Coupdunnit: What Really Happened in Iran?” 
personal memoir of the coup in August 1979. The book was withdrawn from publication after only 400 copies were published, and then re-released after the conclusion of the Iranian hostage crisis in $1981 .{ }^{8}$ Roosevelt's Countercoup was the first open-source CIA history of the coup that described US involvement in detail. ${ }^{9}$ Subsequently, the Iranian hostage crisis began in November of 1979, indicating that the memoire may have fueled the narrative behind the student protests. The ongoing debate surrounding the coup has heightened in significance in 2015 as the United States is engaging Iran on a wide variety of issues, to include Iran's nuclear program, the lifting of economic sanctions, and potential cooperation between the two countries in the effort to combat the growing threat posed by Islamic State of Iraq and the Levant (ISIL).

A careful examination of the historical record reveals a complex web of interests by actors both internal and external to Iran, within the context of the early years of the Cold War. The Anglo-Iranian oil crisis, which spanned the presidencies of both Harry S. Truman and Dwight D. Eisenhower, set off the sequence of events that eventually culminated with Operation Ajax. Prior to President Eisenhower’s ultimate approval of Operation Ajax, multiple attempts were made by President Harry Truman’s administration to resolve the conflict through diplomatic negotiations. Some scholars have argued that the efforts by the Eisenhower administration to resolve the crisis through military means represented a distinct policy divergence from the earlier Truman administration. The divergence is frequently attributed to the personalities of Eisenhower's Secretary of State, John Foster Dulles, and his brother, Allen Dulles, the Director of

Foreign Affairs (September/October 2014), 163-165; and Mostafa T. Zahrani, "The Coup that Changed the Middle East: Mossadeq Vs. The CIA in Retrospect,” World Policy Journal 19, no. 2 (2002): 93-99.

${ }^{8}$ Balaghi, 81.

${ }^{9}$ Kermit Roosevelt, Countercoup: The Struggle for the Control of Iran (New York, NY: McGraw-Hill, 1979). 
Central Intelligence. ${ }^{10}$ Others have argued that significant policy continuities existed between the two administrations, and that their efforts represent a graduated approach to changing circumstances that reflected shared principles. ${ }^{11}$ As Zachary Karabell noted, historians who distill the different approaches by the two administrations to different personalities are usually overlooking changing circumstances and tactics that were quickly changing during the crisis. ${ }^{12}$

Much academic literature has already been devoted to the study of the specific events that took place during Operation Ajax to determine the extent of the United States' involvement and intentions in the coup. ${ }^{13} \mathrm{~A}$ less studied aspect of the coup is the role that strategic intelligence estimating had in informing and influencing both the Truman and Eisenhower administrations. Interestingly, the prominence and credibility of the CIA as an intelligence organization expanded dramatically during the period of 1947 to 1953 and coincided with the execution of the coup. An analysis of the State Department and CIA's assessments of the Iranian Crisis provides insight into the impact that the interagency intelligence community's assessments had in shaping the decisions made by the Truman and Eisenhower administrations.

${ }^{10}$ For an example of this position, see Bruce Robellet Kuniholm, The Origins of the Cold War in the Near East (Princeton, NJ: Princeton University Press, 1980), 435.

${ }^{11}$ See George C. McGhee, "Recollections of Dr. Muhammad Mussadiq,” in Mussadiq, Iranian Nationalism, And Oil, eds. James A. Bill and William Roger Louis (Austin, TX: University of Texas Press, 1988), 304; Steven Marsh, “Continuity And Change: Reinterpreting The Policies Of The Truman And Eisenhower administrations Toward Iran, 1950-1954,” Journal of Cold War Studies 7, no. 3 (Summer 2005): 79-123; Francis J. Gavin, "Politics, Power, and US Policy In Iran, 1950-1953,” Journal of Cold War Studies 1, no. 1 (Winter 1999): 56-89; and Zachary Karabell, Architects of Intervention: The United States, The Third World and the Cold War, 1946-1962 (Baton Rouge, LA: Louisiana State University Press, 1999).

${ }^{12}$ Karabell, Architects of Intervention, 51.

${ }^{13}$ For more on the events that occurred during the execution of Operation Ajax, see Kermit Roosevelt, Countercoup, The Struggle for the Control of Iran (New York, NY: McGrawHill, 1979); Stephen Kinzer, All The Shah's Men (Hoboken, NJ: J. Wiley \& Sons, 2003); Malcolm Byrne and Mark J Gasiorowski, Mohammad Mosaddeq and the 1953 Coup in Iran (Washington, DC: National Security Archive, 2004); and Ervand Abrahamian, The Coup (New York, NY: The New Press, 2013). 
This monograph contributes to the body of literature by synthesizing archival materials with recent political science commentary on intelligence operations to analyze the impact that the CIA had in informing and influencing the Truman and Eisenhower administrations. This monograph argues that structural and organizational impediments minimized the influence of the Office of National Estimates (a component of the analytic wing of the CIA) during the first year of the Eisenhower administration. ${ }^{14}$ Specifically, this monograph asserts that the organizational structure of the CIA exacerbated inherent analyst-policymaker tensions and facilitated a severe case of “groupthink” among President Eisenhower’s closest advisors. ${ }^{15}$ This monograph explores the development of the CIA and the early assessments and coordinating procedures of the analytical branches of the nascent interagency intelligence community. By analyzing a historical record consisting of intelligence estimates, official memoranda, State Department cables, and memoires, this monograph shows that the analytic branch of the CIA (led by the Office of National Estimates), provided the National Security Council (NSC) with multiple wellcoordinated estimates from 1950 to 1953 that accurately reflected the complexity of the Iranian situation. Moreover, this monograph argues that continuities did exist between the Truman and Eisenhower administrations, but the manner in which the two administrations leveraged the analytic branch of the CIA (both in developing situational understanding and providing covert options) during the Anglo-Iranian Oil Crisis marked a distinct procedural difference between the two presidents that ultimately shaped their policies toward Iran.

${ }^{14}$ The CIA consisted of two primary branches: The Directorate of Intelligence, which is responsible for coordinating and analyzing intelligence reporting; and the Directorate of Plans, which was responsible for covert operations, to include covert intelligence gathering.

${ }^{15}$ A leading scholar on groupthink, Irving Janis, describes the phenomenon as "a mode of thinking that people engage in when they are deeply involved in a cohesive in-group, when the members' strivings for unanimity override their motivation to realistically appraise alternative courses of action. See Irving Janis, Victims of Groupthink (Boston, MA: Houghton, Mifflin, 1972), 9. 
A history of the early Cold War Years (1945-1953) is briefly surveyed in Section One, in order to explain the strategic and political context leading up to the Anglo-Iranian Oil Crisis. The history of the development of the CIA, early intelligence analytic methodology, and intelligence estimation are explored in Section Two. A brief summary of the Anglo-Iranian Oil Crisis prior to the execution of Operation Ajax is provided in Section Three. A detailed analysis of the intelligence estimates and policy papers produced during the Anglo-Iranian Oil Crisis are analyzed in Sections Four and Five in order to identify the continuities and discontinuities between the Truman and Eisenhower administrations. Lastly, in order to assess the influence that the CIA (as part of the broader interagency intelligence community) had in shaping decisions by two presidential administrations, the monograph concludes with a synthesis of the historical record presented in previous sections with current frameworks that are relevant to intelligence analysis. Conspicuously absent in this monograph is any summary of Operation Ajax itself. Operation Ajax has already been discussed extensively in academic literature, and does not facilitate the purpose of analyzing the decision-making processes that led to the coup.

For decades, both the US government and the British government concealed and denied their involvement in the planning and execution of the coup. ${ }^{16}$ As of January 2015, the CIA has not declassified several key historical documents that would verify the CIA's role in the coup, to include a CIA historical paper written by planner and historian Donald Wilber in 1954, entitled “Overthrow of Premier Mosaddeq of Iran, November 1952-August 1953.” In November 2000, the Donald Wilber history was leaked to the New York Times and published at the privately run

${ }^{16}$ For more on the history of US and British secrecy and declassification efforts related to the coup, see Shiva Balaghi, "Silenced Histories and Sanitized Autobiographies: The 1953 CIA Coup in Iran,” Biography 36, no. 1 (Winter 2013): 71-96; Tim Weiner, “C.I.A. Destroyed Files On 1953 Iran Coup,” The New York Times, 29 May 1997; and Malcolm Byrne, “The Secret CIA History of the Iran Coup, 1953,” National Security Archive Electronic Briefing Book No. 28, 29 November 2000, accessed 1 September 2014, http://www2.gwu.edu/ nsarchiv/NSAEBB /NSAEBB28. 
National Security Archive. ${ }^{17}$ In August 2013, as a result of a Freedom of Information Act (FOIA) request, the CIA declassified additional portions of another internal history, entitled Battle for Iran, publicly confirming its involvement in the coup for the first time. ${ }^{18}$

The National Security Archive is continuing to call for the release of all remaining classified records regarding the coup, including the Donald Wilber history. For decades historians have pressed for improved accuracy in the State Department's Foreign Relations of the United States (FRUS) series. Volume X of the series, entitled “Iran 1951-1954,” is missing many key documents that detail US involvement in the coup. Historian Bruce Kuniholm wrote a report to the US Department of State Advisory Committee on Historical Diplomatic Documentation, in which he asserted that "the Iran volume [is] a gross misinterpretation of the historical record sufficient to deserve the label of fraud." ${ }^{19}$ The US government's sixty-year reluctance to be fully transparent about its involvement in Operation Ajax presents modern day dilemmas. Declassified documents at the Dwight D. Eisenhower Presidential Library explain the concerns about the importance of maintaining secrecy in order to protect US national interests and capabilities, as evidenced by President Eisenhower's reflections in his confidential files:

Another recent development that we helped bring about was the restoration of the Shah to power in Iran and the elimination of Mossadegh. The things we did were 'covert.' If knowledge of them became public, we would not only be embarrassed in that region, but our chances to do anything of like nature in the future would almost totally disappear. ${ }^{20}$

${ }^{17}$ As the CIA has not declassified the original Wilber document, it has not been referenced as a primary source document in this paper. However, the historical record regarding Operation Ajax is largely based on the Wilber history, therefore secondary source materials analyzing the document have been incorporated into this monograph.

${ }^{18}$ Malcolm Byrne, “CIA Confirms Roles in 1953 Iran Coup,” National Security Archive Electronic Briefing Book No. 435 (19 August 2013), accessed 1 September 2014, http://www2.gwu.edu/ nsarchiv/NSAEBB/NSAEBB435

${ }^{19}$ Kuniholm, 435.

${ }^{20}$ Dwight D. Eisenhower, Diary Entry, October 8, 1953. Box 3, DDE Diary Series. Dwight D. Eisenhower Presidential Library. [The Dwight D. Eisenhower Presidential Library will herein after be referred to as DDEL]. 
In 2000, in what was likely an attempt to change the narrative between the United States and Iran, then United States Secretary of State Madeleine Albright publicly acknowledged the coup in an address to the American-Iranian Council when she stated that, "the Eisenhower administration believed its actions were justified for strategic reasons, but the coup was clearly a setback to Iran's political development. And it is easy to see now why many Iranians continue to resent this intervention by America in their internal affairs." ${ }^{21}$ It is noteworthy that the US government has openly acknowledged its role in the coup, and yet the CIA still refrains from declassifying insightful documents that might contribute to the historical analysis of the operation.

The ongoing declassification of historical documents surrounding Operation Ajax contributes to the understanding of the US intelligence community's development. As the CIA's Chief Historian noted during a briefing to the School of Advanced Military Studies, covert action is “an indispensable but controversial element of US foreign policy.” 22 Indeed, controversies surrounding the CIA are not only limited to covert operations, but have in the past decade extended to other intelligence functions, to include analysis. Since September 11, 2001, a series of intelligence "post-mortems" have been conducted to determine why the interagency intelligence community occasionally fails. ${ }^{23}$ This monograph demonstrates that the controversy

${ }^{21}$ Madeleine K. Albright, Remarks Before the American-Iranian Council, Federation of American Scientists (17 March 2000). Accessed 16 December 2014, http://www.fas.orgnews. /iran/2000/000317.htm. Secretary Albright described the speech as an effort to engage the recently elected Iranian president, Mohammed Khatami, in open dialogue. Khatami had been elected on a mandate of reform, causing the U.S. State Department to perceive an opportunity for improved relations between the two nations. Albright assessed that her efforts were unsuccessful due to the superseding power of Ayatollah Khomeini over President Khatami. See Madeleine Korbel Albright and William Woodward, Madam Secretary (New York, NY: Miramax Books, 2003), 319-326.

${ }^{22}$ David Robarge, “CIA and Covert Action,” presentation delivered to the School of Advanced Military Studies, Fort Leavenworth, KS, 12 November 2014.

${ }^{23}$ For studies of intelligence failures and proposals from improved analytic processes see Richard L. Russell, Sharpening Strategic Intelligence (Cambridge, UK: Cambridge University Press, 2007); Robert Jervis, Why Intelligence Fails (Ithaca, NY: Cornell University Press, 2010); and Milo Jones and Philippe Silberzahn, Constructing Cassandra (Stanford, CA: Stanford University Press, 2013). 
surrounding Operation Ajax was due largely to flawed presidential policy decision-making processes and structural impediments within the CIA, not analytical failures by intelligence analysts. By examining Operation Ajax, this study explores how the CIA as an institution and the broader interagency intelligence community was employed during the early Cold War years. Ultimately, the CIA's analytical branch effectively informed, but ineffectively influenced, the Eisenhower administration’s decision to intervene in Iran. 


\section{Section One}

\section{The Early Cold War Years (1945-1950)}

How had things come to such a pass that a Roosevelt was sneaking around at midnight, hiding under blankets, while Eisenhower altered a speech and Churchill used the BBC for personal messages, all in support of a potential dictator whose sole political objective was to overthrow a highly popular prime minister in favor of a pro-Nazi general? A brief answer is that oil and communism make a volatile mixture. A fuller response takes into account the complexities of postwar international relations and the recent history of Iran.

—Stephen Ambrose, Ike's Spies: Eisenhower and the Espionage Establishment

Historians and political scientists have not achieved a consensus as to the origins of the Cold War. Many argue that the Iranian Crisis of 1945-1946 represents the first overt Cold War rivalry between the United States and the Soviet Union, whereas others maintain that the 1948 Soviet-sponsored coup in Czechoslovakia marked the beginning of the US policy of containment. ${ }^{24}$ While it is debatable whether the Iranian Crisis of 1945-1946 initiated the Cold War, it incontrovertibly had a psychological impact on US decision-makers that influenced the formulation of US foreign policy for decades. ${ }^{25}$ Prior to the crisis, US officials attempted to settle disputes between World War II Allies through negotiation, largely due to the fact that US leaders hoped for continued cooperation between Allies and policy with regard to the Soviet Union did not exist at the time. After the crisis, as tensions developed between the Allies and the tactics of arbitration and negotiation proved increasingly ineffectual with the Soviets, a balance of power strategy re-emerged in US foreign policy. Events in the Near East in 1945-1946 (to include Iran, Turkey, and Greece) therefore played a pivotal role in the development of US foreign policy during the Cold War.

${ }^{24}$ John Lewis Gaddis, The United States and The Origins of the Cold War, 19411947 (New York, NY: Columbia University Press, 1972), 341.

\footnotetext{
${ }^{25}$ Kuniholm, 421.
} 
The Department of State articulated its first stated policy with regard to Iran in 1946, but it was not until 1948 that the United States established a policy for countering Soviet expansionism. For decades prior to World War II, Great Britain and the Soviet Union maintained a longstanding rivalry over informal zones of influence in Iran, which Iranian leaders had consistently rebuffed by playing the great powers against each other in what was known as the Third Party Strategy. ${ }^{26}$ After the collapse of the Soviet-German alliance, the Soviet Union brokered an arrangement with Great Britain to occupy Iranian territory within the historic spheres of influence in order to secure critical supply routes and oil infrastructure. Despite Iran’s objections and proclaimed neutrality, the Soviet Union secured the northern provinces of Iran (to include Azerbaijan), while Great Britain secured the southern provinces that housed their oil investments. ${ }^{27}$

In 1942, the United States Secretary of State, Cordell Hull, sought a formal agreement from both the Soviet Union and Great Britain, officially affirming that their presence in Iran did not represent imperialist ambitions. Hull's efforts led to the negotiation of the Tripartite Treaty of Alliance, which was signed by Iran, Great Britain and the Soviet Union. ${ }^{28}$ The agreement stated that all parties would respect the sovereignty and territorial integrity of Iran and remove forces within six months of the conclusion of the conflict. Mistrusting both the Soviets and the British, the Iranian government repeatedly sought assurances from the United States that its territorial integrity would be guaranteed at the conclusion of the war. The issue of the eventual withdrawal of Soviet and British forces from Iran was also addressed at the Teheran Conference of 1943 and the Yalta and Potsdam Conferences of 1945. The leader of the Soviet Union, Joseph Stalin,

${ }^{26}$ Kristen Blake, The U.S.-Soviet Confrontation In Iran, 1945-1962 (Lanham, MD: University Press of America, 2009), 12.

${ }^{27}$ Michael Burleigh, Small Wars, Faraway Places: Global Insurrection and the Making of the Modern World, 1945-1965 (New York, NY: Penguin Group, 2013), 59.

${ }^{28}$ Blake, 15. 
consistently reassured US officials that the Soviets had no territorial ambitions in Iran. However, he later invoked a 1921 Treaty of Friendship between Iran and the Soviet Union as justification to leave Soviet forces in Iran if the situation remained unstable. ${ }^{29}$

By the end of 1945, the Soviet Union began pursuing expansionist policies in Iran and elsewhere in the Near East. Soviet forces effectively sealed off the northern provinces of Iran from both external and internal forces and actively backed communist-led separatist revolts in Azerbaijan and the Kurdish province of Mahabad. At the same time, the Soviets forcefully pressed the Iranian government for a Soviet-Iranian oil concession similar to that held by the British. Soviet actions in Northern Iran revealed multiple strategic objectives, to include the desire to secure a southern flank, minimize British influence in the region, pressure the Iranian government to agree to an oil concession, and acquire a territorial lodgment for further operations in the Eastern Mediterranean and Middle East. ${ }^{30}$

On February 9, 1946, Stalin delivered a speech in Moscow in which he blamed the Second World War on capitalism and argued that the ideological differences between communism and capitalism would inevitably lead to future wars. US observers viewed Stalin's speech as an indication that communism and capitalism were incompatible. ${ }^{31}$ Two weeks later, a US diplomat at the American Embassy in Moscow, George Kennan, dispatched an 8,000-word telegram known as the "Long Telegram” to the US State Department. The Long Telegram provided a compelling assessment for official Washington, in which Kennan assessed that the communist government of the Soviet Union was diametrically opposed to a peaceful coexistence

\footnotetext{
${ }^{29}$ Ibid., 33-34.

${ }^{30}$ Kuniholm, 379.

${ }^{31}$ Gaddis, 300-301.
} 
with the United States. ${ }^{32}$ Kennan's ideas in the Long Telegram later informed the Truman administration's policy of containment. ${ }^{33}$

The following year, President Truman delivered a speech in which he explained his administration's policy for combatting communism in countries in the Near East, commonly referred to as the Truman Doctrine. ${ }^{34}$ The Truman administration assessed that economic recovery in Eastern European and Mediterranean countries would be critical to the containment of communism, but European allies such as Great Britain were unable to provide aid due to their own post-war economic recovery (the UK was teetering on the brink of bankruptcy after World War II). The Truman administration believed that the United States had a moral obligation to shoulder the burden of defending democracy and would therefore have to bear the economic brunt of recovery. The Truman Doctrine authorized financial aid to Greece and Turkey, but left Iran conspicuously out of the framework. The reason for this was two-fold: The potential revenues generated by Iranian oil were sufficient to resolve Iran's own balance of payments; and the United States was careful not to tread on British interests in Iran. ${ }^{35}$

After the agreed-upon deadline for the withdrawal of forces from Iran passed in May 1946, a crisis emerged when Soviet forces did not withdraw from the northern provinces. The Soviets had inserted armored columns into Northern Iran as early as March 1946 in what

32 Telegram, “The Long Telegram,” George Kennan to James Byrnes, 22 February 1946, Harry S. Truman Administration File, Elsey Papers. Harry S. Truman Library. Accessed 30 September 2014, http://www.trumanlibrary.org/whistlestop/study_collections/ coldwar/documents/index. [The Harry S. Truman Presidential Library will herein after be referred to as HSTL].

${ }^{33}$ For an example of popular perceptions at the time regarding the Soviet threat, see Martin Sicker, The Bear and the Lion: Soviet Imperialism and Iran (New York, NY: Praeger Publishers, 1948), 55.

${ }^{34}$ Harry S. Truman, “The Truman Doctrine.” Address Before a Joint Session of Congress (12 March 1947), accessed 30 September 2014, http://avalon.law.yale.edu/ 20th_century/trudoc.asp.

\footnotetext{
${ }^{35}$ Blake, 44.
} 
appeared to be preparations for an armored thrust toward Tehran. ${ }^{36}$ Stalin justified these actions by declaring that the oil fields at Baku were of critical strategic importance to the Soviet Union and must remain secured during the ongoing separatist revolts. ${ }^{37}$ Using a skillful negotiating maneuver, the Iranian prime minister at the time, Ahmed Qavam, was eventually able to thwart Stalin and convince the Soviets to leave Iranian territory when he promised an oil concession that was contingent on Majles (Iranian parliament) approval. After the final Soviet troops withdrew, the Majles, led by Mohammed Mosaddeq, promptly blocked the bill for the pending Soviet oil concession.

A similar crisis emerged over Turkey shortly afterward, when Soviet brinksmanship visa-vis the Turkish Straits pushed the United States to begin planning and preparing for war. ${ }^{38}$ As historian Edouard Mark surmised, American officials never considered war with the Soviet Union a possibility until the simultaneous crises in Iran and Turkey in 1945-1946. Prior to these crises, diplomatic negotiations and trusteeships were the preferable instrument of power for dealing with the Soviet Union. ${ }^{39}$ President Harry Truman described the escalating situation in a letter to Secretary of State Byrnes in January 1946: “There isn’t a doubt in my mind that Russia intends an invasion of Turkey and the seizure of the Black Sea Straits to the Mediterranean. Unless Russia is faced with an iron fist and strong language another war is in the making. Only one language do they understand-'how many divisions have you?'”40 The policy of containment therefore called

${ }^{36}$ Kuniholm, 323.

${ }^{37}$ Burleigh, 61.

${ }^{38}$ Edouard Mark, “The War Scare Of 1946 and its Consequences,” Diplomatic History 21, no. 3 (1997): 387.

${ }^{39}$ For an example of trusteeship policies, see William Roger Louis, Imperialism At Bay (New York, NY: Oxford University Press, 1978), 448-450. President Franklin D. Roosevelt nearly proposed a joint trusteeship at the Yalta Conference to construct a railroad originating at the Persian Gulf and terminating in the Soviet Union. The goal was to promote economic cooperation between the Great Powers.

${ }^{40}$ Gaddis, 281. 
for the establishment of a large peacetime military capable of deterring Soviet aggression and responding to global security requirements.

The showdown between the United States and Soviet Union in Iran, Turkey, and Greece had multiple effects in the following decades. First, it promulgated fears of the spread of communism and exposed Soviet tactics in the Near East and elsewhere. The Iranian Crisis was in essence the catalyst that set in motion the Truman Doctrine and the US policy of containment. Events in Iran, Turkey, and Greece from 1945 to 1946 also solidified the strategic importance of the Near East in the minds of US policymakers. Lastly, the 1945-46 crisis set the conditions for future confrontations over Iran. Mohammed Mosaddeq's role in resolving the Iranian Crisis of 1945-1946 increased his political prestige, which was accompanied by a fierce wave of nationalism that placed increasing demands on the Anglo-Iranian Oil Company (AIOC). The Iranian public resented the British-Soviet rivalry over their resources and viewed the nationalization of their oil industry as vital to their independence from imperial powers. ${ }^{41}$

As historians debate the role of the Iranian Crisis in the emergence of the Cold War, it is important to note that events in Iran in 1945 represented a unique confluence of incompatible ideologies, economic ambitions, and emerging Persian nationalism. It would be an oversimplification to place blame for the crisis squarely on Soviet expansionist policies. Eventually, the analysis of the Soviet threat that informed the policy of containment transformed into an “ideological lens” through which almost all US foreign policy decisions were viewed for decades. ${ }^{42}$ In the end, the United States government's preoccupation with communist machinations in Iran overshadowed its awareness of internal drivers of instability, which may explain the Eisenhower administration's decision to use covert action in Iran, and the fact that the 1978 Iranian Revolution surprised the US government.
${ }^{41}$ Sicker, 84.
42 Blake, 190. 


\section{Section Two}

\section{The Birth of the Central Intelligence Agency and National Intelligence Estimating}

It is obviously desirable for the government officials making national security decisions to have available in written form the best composite judgments of the interagency intelligence community on the main strategic situations affecting US security.

—Ray Cline, Former Deputy Director of the CIA

The formative years of the Central Intelligence Agency coincided with the early years of the Cold War and the creation of the US national security establishment, to include the Joint Chiefs of Staff and the National Security Council. As a result, Cold War prerogatives and the parochial interests of the interagency intelligence community heavily shaped the structure, organization and mission of the agency and had long-term impacts on its efficacy and influence. This section explores the lineage and organizational design of the CIA, as well as the early analytic principles of its founding generation.

The origins of the CIA are frequently traced back to the creation of the Office of Strategic Studies (OSS) under President Franklin D. Roosevelt during World War II. The OSS was spearheaded by William “Wild Bill” J. Donovan, a veteran of World War I, and was credited with supplying actionable intelligence to President Franklin Roosevelt and Allied commanders during World War II. ${ }^{43}$ Donovan was a visionary in the sense that he recognized the need for an intelligence agency that could federate the collective assessments of all strategic and operational intelligence organizations. Donovan theorized that centralization would improve intelligence analysis and reduce duplications of effort.

In 1941, Donovan created the Research and Analysis (R\&A) Branch of the OSS, consisting of an elite team of scholars who were responsible for compiling and analyzing

${ }^{43}$ Charles Ameringer, US Foreign Intelligence: The Secret Side of American History (Lexington, MA: Lexington Books, 1990), 174-175. See also Thomas F. Troy, Wild Bill and the Intrepid (New Haven, CT: Yale University Press, 1996); and David F. Rudgers, Creating the Secret State (Lawrence, KS: University Press of Kansas, 2000). 
information from the Department of State, military services, and Library of Congress. The greatest strength of the OSS' R\&A branch was the talent that Donovan recruited at its outset. He assembled a group of academics that "would have put the faculty of any one university to shame." ${ }^{44}$ Some of the most prominent analysts included Sherman Kent, a scholar from Yale, William L. Langer, a history professor from Yale, and Ray Cline, a scholar from Harvard. ${ }^{45}$ Initially, the OSS received most of its intelligence reporting from the State Department. ${ }^{46}$ As documented by one of the founding members of the CIA's National Estimates Board, Ludwell Lee Montague, initial R\&A estimates were not coordinated with other agencies and were overly academic:

The analyses that were actually produced by this R\&A Branch were not estimates. They were academic studies, descriptive rather than estimative... Donovan had no idea of coordinating these studies with anyone. He was responsible only to the President. One can readily imagine how professional Army, Navy, and Foreign Service officers reacted to the idea that a lot of johnny-come-lately professors would be telling the President what to think about political and strategic matters. ${ }^{47}$

This statement shows that the concept of coordinating intelligence analysis across a federated intelligence community was not yet an accepted best practice, and that the OSS (and later the CIA) relied heavily on its direct link to the executive. Moreover, early attempts to centralize intelligence resulted in a turf war amongst the various interagency intelligence organizations, particularly within the military services. ${ }^{48}$ To counter the OSS' influence on military estimates,

${ }^{44}$ As quoted in Ameringer, 166. See also Ludwell Lee Montague, "The Origins of National Intelligence Estimating,” Studies of Intelligence 16, no. 2 (1972): 64.

${ }^{45}$ Each of these analysts produced memoires describing the early formative years of the CIA. See Sherman Kent, Strategic Intelligence for American World Policy (Princeton, NJ: Princeton University Press, 1949); Ray S. Cline, Secrets, Spies, and Scholars (Washington, DC: Acropolis Books, 1976); and William L. Langer, In and Out of the Ivory Tower (New York, NY: N. Watson Academic Publications, 1977).

${ }^{46}$ Ameringer, 180.

${ }^{47}$ Montague, 64. Emphasis added.

${ }^{48}$ Amy B. Zegart, Flawed by Design: The Evolution of the CIA, JCS, and NSC (Stanford, CA: Stanford University Press, 1999), 173. 
US Army General Raymond Lee, who had recently served as an attaché to London, proposed the creation of the Joint Intelligence Committee (JIC), a military intelligence organization modeled after a British system used during World War II. ${ }^{49}$ The JIC is credited with producing many of the US government's first national intelligence estimates. ${ }^{50}$ Although the JIC attempted to develop truly joint estimates, it inadvertently reflected the interests of individual departments rather than unified national interests. Moreover, the JIC’s initial processes and procedures promoted conformity and groupthink:

No one held a power of decision in case of disagreements. Since there was not an acceptable way of registering a divergent view, unanimous agreement was required. In the case of a real controversy, that could be obtained only if someone backed down, or, as happened more often, if someone could devise an ambiguous formulation acceptable to both sides in the controversy. Thus, joint estimates tended to become vague or meaningless precisely at points of critical importance. ${ }^{51}$

While the JIC did attempt to coordinate intelligence estimates in order to produce joint assessments, their processes and procedures were not properly centralized and like the OSS, did not have a mechanism for effective coordination.

After the conclusion of World War II, President Truman expressed reservations about the formation of a permanent intelligence agency during peacetime, referring to the OSS as a “Gestapo.”52 In 1945 he signed an executive order that disbanded the OSS, reflecting American values and concerns about the practice of intelligence collection. At that time, the R\&A branch was relocated to the State Department. ${ }^{53}$ Within a year of dismembering the OSS, President

${ }^{49}$ For background on the JIC, see Michael S. Goodman, The Official History of the Joint Intelligence Committee, vol. I: From the Approach of the Second World War to the Suez Crisis (Hoboken, NJ: Taylor and Francis, 2014); and Richard J. Aldrich, Rory Cormac and Michael S Goodman, Spying on the World (Edinburgh, SCT: Edinburgh University Press, 2014).

${ }^{50}$ Montague, 66.

${ }^{51}$ Ibid., 67. Emphasis added.

${ }^{52}$ R. Harris Smith, OSS: The Secret History of America's First Central Intelligence Agency (Berkeley, CA: University of California Press, 1972), 367.

53 Ameringer, 175. 
Truman concluded that the United States' role in world affairs had expanded significantly after World War II and would require a robust intelligence architecture. Furthermore, concerns of a second Pearl Harbor attack demanded early warning of potential threats. ${ }^{54}$

By this time, the State Department had formed its own analytical wing, known as the Bureau of Intelligence and Research (INR), which analyzed State Department cables and other intelligence reports from outside agencies in order to provide intelligence support to department heads and station chiefs. The State Department initially considered filling the role of the centralized intelligence organization, viewing the Secretary of State as the best candidate to serve as intelligence chief because of his involvement in foreign affairs. However, the State Department also found its intelligence gathering role at odds with its diplomatic mission, fearing that revelation of collection efforts would jeopardize foreign relationships. Ultimately, Donovan intervened when he learned of the State Department's concept and proposed the creation of the Central Intelligence Group (CIG). ${ }^{55}$ His argument was that “departmental intelligence estimates were by their nature self-serving. The President should have in his service an intelligence organization wholly free of the influence of departmental policy advocacy and special

54 The Japanese attack at Pearl Harbor is frequently cited as the first example of strategic surprise, and an intelligence failure, in the history of the US intelligence community. See Roberta Wohlstetter, Pearl Harbor: Warning and Decision (Stanford, CA: Stanford University Press, 1962).

${ }^{55}$ For more information about the Donovan Proposal, see William Donovan, "Donovan Memorandum to the President,” Memorandum (Washington, DC: 1944), Creating Global Intelligence, The Freedom of Information Act Electronic Reading Room, accessed 16 January 2015, https://www.foia.cia.gov; William Donovan, "The Basis for a Permanent United States Foreign Intelligence Service,” Memorandum (Washington, DC: 1944), Creating Global Intelligence Collection, The Central Intelligence Agency Freedom of Information Act Electronic Reading Room, accessed 16 January 2015, https://www.foia.cia.gov; William Donovan, "The Donovan Plan for the Establishment of a Central Intelligence Authority,” Memorandum (Washington, DC: 1944), Creating Global Intelligence Collection, The Central Intelligence Agency Freedom of Information Act Electronic Reading Room, accessed 16 January 2015, https://www.foia.cia.gov. 
pleading.” ${ }^{56}$ Intelligence estimates, Donovan maintained, would inform national security strategy and policy and therefore needed to be independent.

Although Donovan recognized that national intelligence estimates needed to be centralized and independent, Montague noted that neither the Donovan proposal nor the State Department proposal ever contemplated coordinating intelligence across the military departments and interagency. ${ }^{57}$ Both concepts involved a centralized intelligence staff consolidating facts from the interagency and drawing their own independent conclusions, without offering a mechanism for dissenting opinions. Ray Cline, who was one of the leading analysts at the time and later went on to serve as the Deputy Director for Intelligence (DDI), wrote an article about the coordination of intelligence across the interagency. As he noted, coordination was insufficient during the early formative years of the OSS and CIA:

In the old days it was perfectly possible for one agency to produce a little thinkpiece setting forth some preposterous theory about Soviet intentions and through the agency staff channels, present it on the highest policy level without it occurring to anyone to question whether or not this represented the best intelligence views of equally well informed people in the intelligence community. ${ }^{58}$

Interagency rivalries impeded the development of a federated intelligence architecture that could successfully coordinate estimates. The various intelligence organizations feared that an overly centralized CIA would not serve the interests of the individual services. An intense debate ensued and ultimately resulted in the adoption of a compromise plan submitted by the JIC, known as JIC 239/5 (1 January 1945), which called for the Director of Central Intelligence to consult with a board composed of departmental and agency heads in order to obtain their concurrence or dissent

${ }^{56}$ Montague, 68.

${ }^{57}$ Ibid.

${ }^{58}$ Ray S. Cline, “Is Intelligence Over-Coordinated?” Studies of Intelligence 1, no. 4 (1957): 14, accessed 14 January 2015, https://www.cia.gov/library/center-for-the-study-ofintelligence/kent-csi/vol1no4/html/v01i4a02p_0001.htm. 
on all national intelligence estimates. ${ }^{59}$ The armed services backed JIC 239/5 for fear of Donovan's intrusions into military intelligence. ${ }^{60}$ Despite the rampant bureaucratic infighting, the requirement for federated, coordinated, interagency and interdepartmental intelligence estimates was formalized in JIC 239/5 and JCS $1181 .^{61}$

The Central Intelligence Group was therefore formed in 1946 from the vestiges of the OSS, with newly mandated processes and procedures for federation and coordination. The position of the Director of Central Intelligence was created and placed under the direction of the president, thereby giving the intelligence community a central role in informing policy.

Additionally, the National Intelligence Advisory Board was created to ensure that estimates were properly coordinated across the interagency. In 1947, the CIG was renamed the Central Intelligence Agency and given its own budget with the passage of the National Security Act, which concurrently formed the National Security Council. ${ }^{62}$

The CIA was envisioned as an organization that would centralize and coordinate the intelligence community without disrupting or duplicating the efforts of adjacent and subordinate intelligence organizations. As its formation was concurrent with the creation of the National Security Council, it quickly obtained a natural role in assisting policy planning. The National Security Act mandated that the CIA make recommendations to the National Security Council,

${ }^{59}$ JIC 239/5 was temporarily shelved after it was leaked to the press. It was later resurrected as JCS 1181, but the latter proposal was almost identical to the initial proposal.

${ }^{60}$ Larry A. Valero, "The American Joint Intelligence Committee and Estimates of the Soviet Union, 1945-1947,” Studies in Intelligence (Summer 2000): 65-80.

${ }^{61}$ For more on JIC 239/5 Compromise, see "Report by the Joint Strategic Survey Committee to the JCS on JCS 1181 and JIC 239/5.” Report. (Washington, DC, 1945), Creating Global Intelligence Collection, The Central Intelligence Agency Freedom of Information Act Electronic Reading Room, accessed 16 January 2015, http://www.foia.cia.gov.

${ }^{62}$ Ameringer, 181. For more on the organization of the CIA, see John Ranelagh, The Agency: The Rise and the Decline of the CIA (New York, NY: Simon and Schuster, 1986); Amy B. Zegart, Flawed by Design (Stanford, CA: Stanford University Press, 1999); and Athan G. Theoharis, The Central Intelligence Agency: Security Under Scrutiny (Westport, CT: Greenwood Press, 2006). 
coordinate the work of the intelligence community, and produce national intelligence estimates. Montague noted that after the adoption of JIC 239/5, the various agencies that were supposed to serve as contributors to national intelligence estimates refused to do so, forcing the Central Intelligence Group to produce estimates in a vacuum. ${ }^{63}$ In response to this bureaucratic inertia, the CIG began to expand covert operations as a unique niche within the interagency intelligence community. The problem of coordination was not improved until General Walter Bedell "Beedle” Smith became the Director of Central Intelligence in 1950 and established the Office of National Estimates (ONE) in response to the CIA's failure to predict the Korean War. ${ }^{64}$

Although the State Department formally surrendered the role of coordinating intelligence for US government policymakers, it did maintain a large role in determining how intelligence would influence policy decisions in the early years of the National Security Council. ${ }^{65}$ The role of the State Department in guiding the CIA became even more pronounced when Walter Bedell Smith, having served as a former chief of staff to then General Eisenhower during World War II, brought with him to DC former OSS agent Allen Dulles. ${ }^{66}$ When Eisenhower assumed the presidency in 1953, he elevated Allen Dulles to the head of Central Intelligence and appointed his brother, John Foster Dulles, as the Secretary of State, effectively soldering the assessments of the CIA and policy positions of the State Department together for a period of eight years.

A study by the Joint Strategic Survey Committee on JIC 239/5 and JCS 1181 noted that "synthesis and dissemination of intelligence is probably the most important function of the Central Intelligence Agency, and presents the most promising field for improvement over the

${ }^{63}$ Montague, 69.

${ }^{64}$ For more on General Walter Bedell Smith's tenure as the Director of Central Intelligence, see Ludwell Lee Montague, General Walter Bedell Smith as Director of Central Intelligence, October 1950-February 1953 (University Park, PA: Pennsylvania State University Press, 1992).

\footnotetext{
65 Ameringer, 196.

66 Smith, 367.
} 
present system," but it also contained an elastic clause calling for the CIG to "perform such other functions and duties related to intelligence as the National Intelligence Authority may from time to time direct.” ${ }^{\prime 67}$ This “elastic clause” was carried over to the National Security Act of 1947, and was quickly interpreted by the CIA as a loophole that authorized covert and clandestine operations. After the CIA failed to secure the full support and cooperation of all contributing intelligence agencies, its frustrated (and disinterested) leadership focused less on the production of national intelligence estimates and increased its focus on clandestine operations. These pressures, coupled with a direct reporting line to the Oval Office, caused covert operations to grow disproportionately to its analytic wing, ultimately becoming the primary focus of the CIA ${ }^{68}$ As Amy Zegart noted in her book, Flawed by Design, "many of the excesses, problems, and scandals of the CIA have organizational roots." ${ }^{69}$ When designing the OSS, Donovan created a bifurcation between intelligence analysis and intelligence operations within the agency that carried over into the CIA. Like many of his successors, Donovan took a greater interest in clandestine operations over the more mundane analytical work that was assigned to the OSS' Research and Analysis branch. As a result, the R\&A Branch of the OSS had little interaction with its adjacent operations branch, known as the Secret Intelligence (SI Branch), and the two organizations developed vastly different cultures and missions that carried over into the CIA. ${ }^{70}$ This is interesting, because as Zegart pointed out, the CIA was never given the mandate to conduct covert operations. ${ }^{71}$ It was supposed to coordinate intelligence analysis for the president, and yet it was poorly equipped to do so largely because of interagency rivalries and a
${ }^{67}$ Ameringer, 196.
${ }^{68}$ Ibid., 200-201.
${ }^{69}$ Zegart, 3
${ }^{70}$ Ameringer, 158.
${ }^{71}$ Zegart, 163. 
disproportionate allocation of money and interest to the Directorate of Plans, the CIA's covert wing. Covert operations were not explicitly authorized, but vague wording in the 1947 National Security Act provided a sizeable loophole for the development of covert capabilities.

The CIA’s preeminent interest in clandestine operations continued with Allen Dulles' tenure as the Director of Central Intelligence. Dulles’ preferences are evident in his 1963 book, entitled The Craft of Intelligence, in which he attempted to explain intelligence operations to the public. $^{72}$ Several of Dulles’ contemporaries, to include Frank Wisner, a former Director of Plans at the CIA, noted his central focus on covert and overt intelligence operations, and a conspicuous absence of any detailed discussion regarding analytic methods:

It is believed that the author might himself be willing to acknowledge the existence of an imbalance in favor of intelligence tradecraft, i.e., clandestine techniques and operations, and to the disadvantage of certain of the most important functions and problems of research and analysis and estimative processes. ${ }^{73}$

Over time, the CIA's clandestine activities garnered a poor reputation across the interagency intelligence community, which exacerbated collaboration with the Federal Bureau of Investigations and the respective intelligence wings of the military services. ${ }^{74}$ Despite the best intentions of its founders to coordinate intelligence estimates, the CIA was plagued with problems

72 Allen Dulles, The Craft of Intelligence (New York, NY: Harper \& Row, 1963). The title of Dulles' book is interesting because of his reference to the "intelligence tradecraft." Scholars from the social sciences in the past decade have commented that one of the persistent deficiencies of the intelligence community is its adherence to the notion of intelligence as a tradecraft rather than a discipline, and its reluctance to adopt analytical methodologies similar to medicine, law, or library science. For more on this argument, see Rebecca Fisher and Rob Johnston, “Is Intelligence Analysis a Discipline?” Analyzing Intelligence: Origins, Obstacles and Innovations, eds. Roger Z. George and James B. Bruce (Washington, DC: Georgetown University Press, 2008), 55-70.

${ }^{73}$ Frank Wisner, “On 'The Craft Of Intelligence.’” Studies of Intelligence 8, no. 1 (1964): A1-A16, accessed January 14, 2015, https://www.cia.gov/library/center-for-the-study-ofintelligence/kent-csi/vol8no1/html/v08i1a07p_0001.htm.

\footnotetext{
${ }^{74}$ Ameringer, 175.
} 
of "stovepiping" — both externally with outside organizations, and internally between its various branches-from the very beginning of its existence. ${ }^{75}$

Despite their talent, credentials and expertise, many of the founders of the Research and Analysis Branch (later known as the Office of National Estimates), were disillusioned by the early development of the OSS and the CIA as they met resistance from policymakers who rejected assessments that did not support their policy agendas. ${ }^{76}$ Sherman Kent, considered the “pioneer of strategic intelligence analysis,” wrote extensively about tensions between analysts and policymakers. ${ }^{77}$ During his sixteen years working with the CIA, he devoted a significant amount of effort to improving analytic professional standards in order to reduce those tensions. He articulated his philosophy in a Studies of Intelligence article when he wrote, "let things be such that if our policy-making master is to disregard our knowledge and wisdom, he will never do so because our work was inaccurate, incomplete, or patently biased."78

Prior to joining the R\&A Branch of the OSS, Kent served as a history professor at Yale in the 1930s. After the war, he wrote his book, Strategic Intelligence for American World Policy. Publishers were initially reluctant to support Kent's book because of its emphasis on intelligence analysis, rather than the more exciting topic of covert action. ${ }^{79}$ Princeton University Press eventually published the book, which became a landmark reference for the intelligence community.

75 "Stovepiping" is a term that was coined to describe poor coordination and sharing of intelligence products. For more on the phenomenon, see Jervis, Why Intelligence Fails, 132.

${ }^{76}$ Ameringer, 166.

77 Jones and Silberzahn, 6.

${ }^{78}$ Sherman Kent, “Estimates and Influence,” Studies of Intelligence 12, no. 3 (1968): 12, accessed January 14, 2015, https://www.cia.gov/library/center-for-the-study-of-intelligence/kentcsi/vol12i3/html/v12i3a02p_0001.htm.

${ }^{79}$ Jack Davis, Sherman Kent and the Profession of Intelligence Analysis (Washington, DC: Central Intelligence Agency Sherman Kent Center for Intelligence Analysts, 2002), 5. 
Kent defined intelligence estimating as "what you do when you do not know,” and intelligence estimates as "foreign intelligence documents which begin to examine a subject from the point of view of what is known about it, and then move on beyond the world of knowing and well into the world of speculating." ${ }^{80}$ The problem, Kent observed, occurs when an estimate disagrees with a policymaker's assessment of a situation, causing the policymaker to attack the estimate in order to remain relevant:

The completed estimate will be bad news to one if not more of its important readers: it may undercut a long-held position or destroy a line of painfully developed argument; it may indicate the unwisdom of a plan or the malallocation of large sums of money. Another thing you may be sure of is that he will react as any recipient of bad news reacts-the reflex is one of "I don't believe you." 81

If all other aspects of the estimate are factually correct and free of overt bias, the softest target in the estimate is the point where the analyst was forced to speculate-the portion which is open to debate and interpretation. Kent theorized that the goal of the analyst therefore should be accuracy and credibility, with the hope that influence is achieved in the process. Kent concluded that "at a minimum, the intelligence estimate will have made its contribution in the way it promoted a more thorough and enlightened debate and a higher level of discourse within the high policy-making echelon.” Kent’s colleague, Ray Cline, shared similar views regarding analyst-policymaker tensions. In his memoir, Secrets, Spies, and Scholars, he argued that "NIEs [National Intelligence Estimates] ought to be responsive to the evidence, not the policymaker." ${ }^{82}$ He also made the case that "the analysts... should associate closely on a bureaucratic and intellectual plane with the policymakers who are users of intelligence.” ${ }^{83}$
${ }^{80}$ Kent, 13-14.
${ }^{81}$ Ibid., 17.
${ }^{82}$ Cline, Secrets, Spies, and Scholars, 140.
${ }^{83}$ Ibid, 139. 
The history of the CIA indicates that the founding members of the Office of National Estimates were aware of the benefits of coordination in developing unbiased analytic products. The structure of the CIA internally, and its relationships with the interagency externally (to include the State Department and military service branches) often impeded attempts to coordinate intelligence analysis effectively. ${ }^{84}$ Despite these structural and institutional barriers, Section 4 demonstrates that the National Intelligence Estimates produced during the Truman administration pertaining to Iran were indeed coordinated among the interagency intelligence community and reflected balanced analytical methods. The national intelligence estimates produced during the Truman administration were referenced in corresponding policy documents, indicating that they effectively informed and influenced policy.

${ }^{84}$ See Ray S. Cline, “Is Intelligence Over-Coordinated?” Studies of Intelligence 1, no. 4 (1957): 11-18, accessed 14 January 2015, https://www.cia.gov/library/center-for-the-study-ofintelligence/kent-csi/vol1no4/html/v01i4a02p_0001.htm. 


\section{Section Three}

\section{The Anglo-Iranian Oil Crisis}

How real were the risks in what Mosadeq was doing? Had the British sent in the paratroops and warships, as they were to do a few years later against the Egyptians at Suez, it was almost certain that the Soviet Union would have occupied the northern portion of Iran by invoking the Soviet-Iranian Treaty of Friendship of 1921.

_CIA Internal History, Battle for Iran

To understand the complexity of Iranian politics in the early 1950s, a brief contextual review of the Anglo-Iranian Oil Crisis is necessary. Dr. Mohammed Mosaddeq's rise to the Iranian premiership in 1951 coincided with an intense nationalistic fervor that was almost singularly fixated on the operation of the Anglo-Iranian Oil Company within Iran's borders. Over time the Iranian people came to associate the AIOC, whose largest shareholder was the British government, with British imperialism and political interference. As a result, Mosaddeq's political mandate was irrevocably tied to the nationalization of the AIOC.

British oil exploration in Iran began in earnest in the early 1900s when Sir John Fisher, the First Sea Lord, spearheaded the transformation of the Royal Navy from coal to oil. The Anglo-Persian Oil Company, as it was known at the time, secured a lopsided contract with the Iranian government in which the Iranian government was due to receive 16 percent of net oil revenues after tax. ${ }^{85}$ The Anglo-Persian Oil Company developed the largest refinery in the world at Abadan. Winston Churchill, then the First Lord of the Admiralty, further seized the opportunity by purchasing $51 \%$ of the Anglo-Persian Oil Company’s shares in $1914 .^{86}$ As early as 1925 , Reza Khan (Muhammed Reza Pavlavi's father who preceded him as the Shah of Iran) recognized the

${ }^{85}$ For a broad survey of oil and world politics, see Daniel Yergin, The Prize (New York, NY: Simon \& Schuster, 1991).

${ }^{86}$ Central Intelligence Agency History Staff, The Battle for Iran, The National Security Archive, A-2, accessed 1 August 2014, http://www2.gwu.edu/ nsarchiv/NSAEBB/ NSAEBB476/. 
disparity in the oil agreement. He also noted other effects of the arrangement: Inequitable standards of living between Iranian and British oil workers and few economic benefits for the Iranian region that housed the refinery. Despite these concerns, Reza Shah agreed to a new sixtyyear oil concession in 1933 that contained improved but still disproportionate terms. ${ }^{87}$

Access to Iranian oil became a matter of strategic importance during the Second World War. While the Soviet Union occupied the northern portion of Iran in order to secure a line of communication with the other allied powers, Britain occupied the southern portion of the country in order to secure the Abadan refinery and ensure access to oil required by the British military. ${ }^{88}$ The Iranian government perceived the occupations as invasions and offered some minimal military resistance. After the occupations, Reza Shah abdicated and the allied powers propped up his young son, Mohammed Reza Pavlavi, allowing Iran to retain a constitutional monarchy.

After World War II, the Iranian public began to chafe at international interference and exploitation that persisted within its borders. In 1950, the Saudi government and the United States’ Arabian-American Oil Company (ARAMCO) agreed to a 50:50 equal profit sharing arrangement after taxes, effectively revolutionizing the international oil industry. ${ }^{89} \mathrm{In}$ response, the Iranian government attempted to negotiate a better contract with the AIOC and called for more equitable terms and better opportunities for Iranian oil workers. The result was a new arrangement known as the Supplemental Agreement, which increased Iranian profits to 20 percent. Mosaddeq, newly elected to the $16^{\text {th }}$ Majles as a leader of the National Front Party, was selected to chair a study of the proposal. Mosaddeq and other members of the National Front quickly determined that the terms of the Supplemental Agreement were inadequate and failed to

\footnotetext{
${ }^{87}$ Ibid., A-4.

${ }^{88}$ Burleigh, 76.

${ }^{89}$ James A. Bill and William Roger Louis, eds. Mussadiq, Iranian Nationalism, and Oil
} (Austin, TX: University of Texas Press, 1988), 5. 
meet Iran's primary stipulations, namely improved profit sharing (after taxes), a smaller foreign footprint, and improved opportunities for Iranian workers. ${ }^{90}$

Sir William Fraser, the chairman of the Anglo-Iranian Oil Company, was intransigent in his position regarding the Supplemental Agreement initially, despite counseling by US government officials that warned of the inevitable effects of the 50:50 Aramco deal. The drawnout negotiations between the Iranian government and Anglo-Iranian Oil Company stoked nationalistic sentiments that impeded meaningful progress. Eventually, Fraser and the AngloIranian Oil Company agreed to a 50:50 arrangement similar to that of ARAMCO, but by that time nationalist sentiment had taken root in Iranian politics and calls for nationalization of the oil industry were at a pitch. ${ }^{91}$ This new proposal coincided the Soviet Union’s unsuccessful attempt to gain an oil concession that was effectively blocked by Mosaddeq's bill which forbade oil concessions with any foreign representatives. The debate surrounding Mosaddeq's bill eventually called into question the legitimacy of the Anglo-Iranian Oil Company's agreement and the Majles began to seriously explore the possibility of nationalizing the company. ${ }^{92}$

The Anglo-Iranian Oil Company convinced the prime minister at the time, General Razmara, that nationalization of the oil industry was infeasible due to technical and financial considerations. On March 3, 1951, in a speech to the Majles, General Razmara supported the Supplemental Agreement and recommended against nationalizing the oil industry. Four days later, on March 7, a terrorist group, Fedayeen-e-Islam, assassinated him. The Majles, led by the majority National Front Party, became entrenched in their position and nominated Mosaddeq as Razmara's successor. ${ }^{93}$ It is probable that Mosaddeq internalized the events that led to his

\footnotetext{
${ }^{90}$ The Battle for Iran, A-6.

${ }^{91}$ Burleigh, 265.

92 The Battle for Iran, A-5.

${ }^{93}$ Burleigh, 265.
} 
political ascendancy, not only as a matter of principal, but also as a matter of survival.

Furthermore, Mosaddeq identified the nationalization of the oil industry as the key to Iran's

independence and economic future. He assumed the office of the premiership on April 30, 1951, and declared the nationalization of the oil industry the following day. 


\section{Section Four}

\section{The Truman Administration's Policy Toward Iran}

Apart from the political risks involved, which have now been clearly revealed, [covert action] would have been rejected on the grounds of international morality. The undue reliance of the Eisenhower Era on subversive methods, which Kennedy attempted to curtail, took a heavy toll on the prestige of our country abroad. It resulted, I believe, in a great loss of confidence in us by other nations, particularly the new nations of the developing world struggling for survival and self-respect after the demise of the colonial era.

—George C. McGhee, Former Assistant Secretary of State

To understand the role that the CIA played in influencing US policy with regard to Iran during the Anglo-Iranian Oil Crisis, it is necessary to compare and contrast the formulation of US foreign policy during both the Truman and Eisenhower administrations. President Truman was elected to serve a second term as president in 1949. A liberal government was also in power in Great Britain at the same time, led by Prime Minister Clement Attlee. Dean Acheson, one of Truman's most loyal advisors from the State Department, was elevated to the position of Secretary of State. Acheson maintained good relations with the head of the Central Intelligence, Walter Bedell Smith. The Secretary of Defense position transitioned from George C. Marshall to Robert Lovett in 1951.

In 1946, the Truman administration articulated a perceived threat to US strategic interests in Iran: "Political and strategic interests require that we should give positive encouragement and assistance in Iran in an endeavor to save it from falling completely under Soviet domination and to rescue it if possible from its present state of partial subservience to the Soviet Union." ${ }^{94}$ In July 1949, the CIA published a detailed estimate on the Tudeh Party in Iran, arguing that the party (although disbanded by the government) would remain an important force in Iranian politics so long as social and economic discontent remained pervasive. However, barring active Soviet

${ }^{94}$ Department of State, “Implementation of US Policy Toward Iran,” 18 October 1946, in Foreign Relations of the United States, 1946, Vol. VII, 535-536. 
intervention, the CIA assessed that the Tudeh Party was incapable of constituting a direct threat to the Iranian government. ${ }^{95}$ By September 1950, the CIA assessed that Prime Minister Ali Razmara's administration was at risk of succumbing to Soviet pressures due to its weak economy and recommended an extensive US aid package to protect Iranian independence. ${ }^{96}$ The State Department's assessment at the time was consistent with the CIA's and identified the ongoing economic depression stoked by the Anglo-Iranian oil crisis, clandestine (albeit significantly reduced) Tudeh activities, and the overall ineffectiveness and fragility of the Iranian government as the central threats to Iranian stability. ${ }^{97}$ Economic considerations appeared paramount as reflected in numerous other State Department documents citing the economic depression in Iran as a potential catalyst for political collapse. ${ }^{98}$ The Assistant Secretary of State for Near Eastern, South Asian, and African Affairs, George McGhee, also recommended a financial aid package to stabilize the Iranian economy, similar to aid packages provided to Greece and Turkey under the Marshall Plan.

After Mosaddeq nationalized the oil industry and seized assets from the Anglo-Iranian Oil Company, the Truman administration encouraged the British to seek an oil concession

${ }^{95}$ Central Intelligence Agency, “The Tudeh Party: Vehicle of Communism in Iran.” 18 July 1949. Digital National Security Archive, accessed 1 August 2014, http://gateway.proquest.com.lumen.cgsccarl.com/openurl?url_ver=Z39.88-2004\&res_dat= xri:dnsa\&rft_dat=xri:dnsa:article:CSE00072. Although it is an official and formal estimate produced by the CIA, this document is not a national intelligence estimate. It likely represents one of the initial efforts by the Research and Analysis Branch to provide a formal estimate for policymakers.

${ }^{96}$ Central Intelligence Agency, “Current Iranian Problem,” Intelligence Memorandum No. 132, 20 September 1950, accessed 1 August 2014, http://www.trumanlibrary.org.

${ }^{97}$ McGhee to Acheson, "Iranian Crisis," 25 April 1950, in Foreign Relations of the United States, 1950, Vol. V, 521-524.

${ }^{98}$ See McGhee to Acheson, "Iranian Crisis," 25 April 1950, in Foreign Relations of the United States, 1950, Vol. V, 521-524; "The Present Crisis in Iran," in Foreign Relations of the United States, 1950, Vol. V, 513; and, Grady to Acheson, State Department Telegram, 12 July 1951, President’s Secretary’s Files, Box 158, 12 July 1951, HSTL. 
through negotiations and began serving in earnest as a neutral broker during deliberations.

American and British officials shared several key objectives in Iran related to the containment of communism and the sanctity of commercial contracts. ${ }^{99}$ However, the US government sympathized with Iranian desires for independence and viewed nationalization as a legitimate ambition. ${ }^{100}$ As Julius Holmes noted in a State Department telegram to Secretary of State Acheson:

We [the US] share Brit[ish] concern over seriousness [of the] situation in Iran and danger to free world; US policies regarding Iran are designed to prevent present situation leading to loss of Iran to communism and are directed towards similar objectives UK seeks to achieve... Our appraisal of the internal political situation in Iran indicates nationalism is a real and potent factor in the present situation. We do not believe our objectives in Iran can be achieved if we take a course of action which would appear to place us in opposition to legitimate aspirations. ${ }^{101}$

American officials were frustrated by what they perceived as British colonial motivations in Iran. ${ }^{102}$ Indeed, the British government was struggling to retain its international prestige as its empire contracted in the aftermath of World War II, while also struggling with a severe balance of payments problem. ${ }^{103}$ The revenues from the Abadan refinery represented Great Britain’s largest overseas investment, which it considered critical for rejuvenating its economy in the

${ }^{99}$ On the sanctity of contracts, see Grady to Acheson, State Department Telegram, 19 August 1951, President's Secretary's Files, Box 158, HSTL. An oil-consultant, Walter Levy, was dispatched to educate Iranian leaders on international oil economics. Iranian intransigence relative to international norms threatened international markets and was unlikely to result in successful negotiations with the British government. As Levy noted, the "US believes seizure by any government of [foreign] owned properties without either paying prompt adequate and [effective] compensation or working out new arrangements mutually [satisfactory] to former owner and government, is not nationalization, but confiscation.”

${ }^{100}$ Bill and Louis, 17.

${ }^{101}$ Holmes to Acheson, State Department Telegram, 28 August 1951, President's Secretary’s Files, Box 158, HSTL.

${ }^{102}$ See Hugh Wilford, America's Great Game: The CIA's Secret Arabists and the Shaping of the Modern Middle East (New York, NY: Basic Books, 2013); and Bill and Louis, 16.

${ }^{103}$ Henderson to Acheson, State Department Telegram, 6 November 1951, in Foreign Relations of the United States, 1952-1954, Vol. X, 260-262. 
aftermath of World War II. Equally important to the British government was maintaining its strategic access to petroleum products while denying them to the Soviet Union. ${ }^{104}$ The British government also feared that a trend of nationalization would spread to other investments, to include the Suez Canal. ${ }^{105}$ The US was less interested in Britain's commercial objectives than it was in preventing the spread of communism. ${ }^{106}$

Several documents point to the fact that senior US State Department officials feared that offensive British military activities to reclaim the Abadan refinery would destabilize Iran or possibly even incite a Soviet intervention. The Soviet Union had signed a Treaty of Friendship with Iran in 1921 that called for Soviet intervention in Iran if any foreign power invaded Iranian territory. ${ }^{107}$ US officials feared that a British seizure of the Abadan Refinery would invoke the 1921 Treaty and initiate a third global war. To the consternation of US officials, the British repeatedly downplayed the threat of Soviet intervention. ${ }^{108}$ Prime Minister Attlee, leader of the British Labour Party, was under increasing pressure from the opposition Conservative Party to restore British prestige through the use of force if necessary. ${ }^{109}$ Ambassador Walter S. Gifford reported to Secretary of State Acheson that the British government was considering the use of military force to obtain at least partial objectives vis-à-vis the Abadan Refinery. Gifford wrote:

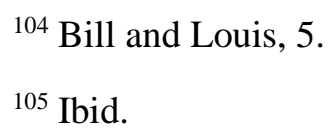
securing a US stake in the Iranian oil industry while simultaneously preventing the nationalization of the Iranian oil industry, for fear that it might inspire a similar nationalization by the Saudis in the Arabian-American Oil Company (ARAMCO) agreement. These interpretations are unlikely, as the US-Saudi ARAMCO deal was already sufficient for US petroleum consumption, while the Saudis benefitted from US technical assistance in the refinement and distribution of petroleum products. For more on US interests see Bill and Louis, 273; and Balaghi, 72.

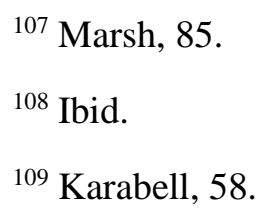


We do wish, however, [to] report to Department our growing conviction that, should negotiations fail and should there be no other prospect restraining Iranians, UK Government would send troops into Abadan. This would be done to protect British lives, but, in our opinion, such a step may lead to decision to hold on to refinery if this proved feasible. Churchill's and Salisbury's remarks leave no doubt that Conservatives would want this done. ${ }^{110}$

Concerns about the Anglo-Iranian Oil Crisis and the potential for the resulting instability to push Iran into the Soviet orbit (and possibly even instigate World War III) greatly concerned US policymakers. Despite this, military intervention, conventional or otherwise, was not actively considered during this period (1950-1951). Rather, the Truman administration initially adopted a policy that emphasized diplomatic negotiations, as dictated in National Security Council Report 107, “US Objectives with Respect to Iran.” National Security Council Report 107 advocated US officials to actively discourage their British counterparts from military intervention: “Although assurances have been received, the United States should continue to urge the United Kingdom to avoid the use of military force in settling the oil controversy.”111

The US State Department sponsored a series of talks in August 1951 in Teheran commonly referred to as "the Harriman Mission,” named after Ambassador Averell Harriman. In addition to negotiating pre-agreed upon concessions to get both sides to the bargaining table, the United States provided oil industry experts to serve as advisors and educators to Iranian authorities. William Langer, then the Assistant Director of the Office of National Estimates at the CIA, published and signed a Memorandum to the Director of Central Intelligence entitled "The Harriman Mission” on 3 August 1951. Langer's memorandum provided an optimistic assessment of the potential outcome from the talks, while also reflecting a detailed understanding of the complicated and fragile British-Iranian relationship. The memorandum acknowledged that Iranian

${ }^{110}$ Gifford to Acheson, Department of State Telegram, 1 August 1951, President’s Secretary's Files, Box 158, HSTL.

${ }^{111}$ National Security Council Report, “Iran,” Statement of Policy 107/2, 27 June 1951, in Foreign Relations of the United States, 1952-1954, Vol. X, 71-73. 
“ultra-nationalist feelings” were likely to clash with British desires to maintain some titular control over operations of the refinery. ${ }^{112}$

US State Department officials displayed a similar understanding of the complexity of the crisis when they observed that a deeply rooted distrust of the British by Iranian officials hampered negotiations. As Grady noted in one telegram, "My discussions with Iranians so far gives me [the] impression that a basic difficulty is their suspicion of [the] British. They fear that British will continue interference in Iranian political affairs and have a feeling of insecurity in their own ability to prevent this.”"113 Talks broke down, largely over Mosaddeq’s refusal to accept any British administration of the refinery, citing that it would equate to another lopsided British concession in disguise. Despite the fact that the Iranian oil industry required British logistical support and expertise to operate effectively, Mosaddeq maintained that he was incapable of conceding to industry standards and norms due to the nationalist movement in his country.

After the talks collapsed, the Attlee government once again approached the Truman administration with proposals to use military force to resolve the dispute. The Truman administration retained its position, and in September the British government decided not to use military force to keep the Abadan Refinery open as it was incapable of doing so unilaterally. ${ }^{114}$ By October, the Labour Party had been voted out, and the Conservative Party returned to power in Great Britain, with Winston Churchill resuming the premiership.

By October 1951, six months after Mosaddeq assumed the premiership in Iran, the CIA produced an internal memorandum that reflected a more alarming assessment of the political situation in Iran. Despite Mosaddeq’s opposition to communism, the Tudeh Party backed him

112 Central Intelligence Agency, “The Harriman Mission,” Memorandum for the Director of Central Intelligence, 3 August 1951, President’s Secretary’s Files, Box 158, HSTL.

${ }^{113}$ Grady to Acheson, Department of State Telegram, 16 August 1951, President's Secretary's Files, Box 158, HSTL.

${ }^{114}$ Bill and Louis, 6. 
because of his anti-British stance, an association that concerned western observers. Citing a recent Tudeh demonstration consisting of over ten thousand demonstrators organized in semimilitary order, and the deteriorating economic situation as a result of British sanctions, the CIA assessed that the Tudeh Party was poised to grow in power. Moreover, it assessed that "the Iranian political pendulum is now swinging dangerously toward the Soviet Union." ${ }^{115}$ It is important to note that this document was an internal CIA memorandum that was disseminated only to the US Embassy in Tehran at the time of its publication. Unlike other CIA documents, it lacked a letterhead and signature block. Indeed, the "From:” heading was blank, and a statement at the beginning reads: "It is specifically requested that no distribution of this report be made outside of the agency.” The internal memorandum was therefore not a coordinated product, which may account for the more alarmist perspective.

Mosaddeq, in his conversations with State Department officials, did indeed insinuate on a regular basis that Iran was likely to fall to communist political forces or seek Soviet aid if it did not receive financial aid from the United States. ${ }^{116}$ Still, while many military and State Department officials perceived the potential for Soviet subversion to turn Iran into a "second China,” other assessments produced by CIA officials were not nearly as alarming. ${ }^{117}$ Despite growing concerns about the spread of communism and the observed social, political, and economic stressors on the Iranian government, initial intelligence assessments during the Truman administration downplayed the potential for a communist takeover in Iran.

${ }^{115}$ Central Intelligence Agency. “Analysis of Iranian Political Situation,” Internal Memorandum, 12 October 1951. President’s Secretary’s Files, Box 158, HSTL.

116 See Grady to Acheson, Department of State Telegram, July 17, 1951, and Grady to Acheson, Department of State Telegram, August 24, 1951. President's Secretary's Files, Box 158, HSTL.

${ }^{117}$ McGhee to Acheson, "Iranian Crisis," 25 April 1950, in Foreign Relations of the United States, 1950, Vol. V, 523. 
As the Anglo-Iranian Oil Crisis proceeded, Great Britain implemented a boycott on Iranian oil sales that pushed Iran into an economic crisis. In January of 1952, Prime Minister Mosaddeq made a formal request to the US government via Ambassador Loy Henderson for financial aid to help mitigate the effects of the boycott, warning that unless financial aid was received within thirty days there would likely be a revolution in Iran. Ambassador Henderson, who was described by one commentator as a "bitterly anti-communist U.S. ambassador” was very concerned about the potential for a communist takeover in Iran. ${ }^{118}$ In a State Department telegram he described his perception of the evolving crisis:

If no foreign aid forthcoming he may be overthrown at last moment by frightened Majlis or as result some kind of coup, or Iran may drift into chaos and disorder out of which may evolve various kinds of regimes, most likely one controlled by Soviet Union...If he should give up hope receiving immediately budgetary aid from US, he might not hesitate, regardless eventual consequences, consummate deal with Russia which might enable his government carry on for time. ${ }^{119}$

In response to Ambassador Henderson's cables, the CIA produced a Memorandum for the Director of Central Intelligence on 17 January 1952, which was then forwarded to President Truman, entitled “Mossadeq’s Demand for Emergency U.S. Aid.” The CIA agreed that the Iranian government was likely to exhaust their emergency funds within thirty days, but that other, less politically popular, financial measures could be taken by the Iranian government to avert a financial crisis. Moreover, the CIA noted that Mosaddeq's demand was anticipated, and that political considerations may have "induced Mossadeq to couch his request for U.S. aid in the strongest possible terms in the hope of convincing the United States that immediate financial assistance to the Mossadeq regime is the only alternative to Communist control of Iran." ${ }^{120}$ The

${ }^{118}$ Burton Hersch, The Old Boys (New York, NY: Charles Scribner's Sons Macmillan Publishing Company, 1992), 332.

${ }^{119}$ Henderson to Acheson, Department of State Telegram, 15 January 1952, in Foreign Relations of the United States, 1952-1954, Vol. X, 323.

${ }^{120}$ Central Intelligence Agency, “Mossadeq’s Demand for Emergency US Aid,” Memorandum for the Director of Central Intelligence, 1 January 1952, President's Secretary’s Files, Box 158, HSTL. 
approving authority, Paul A. Borel, on behalf of the Assistant Director for National Estimates

(William Langer), went on to conclude that although a financial crisis was imminent in Iran, the Soviet Union was unlikely to provide substantial financial assistance and the likelihood of a Tudeh takeover was low, contrary to Ambassador Henderson’s assessment. Interestingly, President Truman acknowledged receipt of the document and inscribed the following message on its coversheet: "I do not think we should make this advance now. HST [Harry S. Truman]." ${ }^{121}$ It would seem intelligence estimates effectively informed and influenced presidential decisionmaking during the Anglo-Iranian Oil Crisis under the Truman administration.

National Intelligence Estimate 46, entitled "Probable Developments in Iran in 1952 in the Absence of an Oil Settlement” provides additional insight into the CIA's assessment of the situation in the aftermath of the collapsed talks. The estimate (dated 4 February 1952), was written in collaboration with the Department of State, the Joint Staff, and the Departments of the Army, Navy and Air Force. At the time, the CIA assessed that the National Front Party remained strong and would be able to meet its financial obligations for at least two to three months, however it assessed that eventually the Iranian government would be unable to provide social and economic benefits to its citizens, and would likely experience an increase in Tudeh popularity. Significantly, the CIA concluded that the National Front, led by Mosaddeq, would be "forced to adapt authoritarian methods." ${ }^{122}$ At the same time, the CIA couched the threat posed by the Tudeh: "We thus believe that barring establishment of authoritarian rule, either by the National Front or by the conservatives, the Tudeh potential for gaining control over the country will substantially increase. However we do not believe that a Tudeh coup is imminent.” ${ }^{123}$ The CIA

${ }^{121}$ Ibid., cover sheet.

${ }^{122}$ Central Intelligence Agency, "Probable Developments in Iran in 1952 in the Absence of an Oil Settlement,” National Intelligence Estimate 46, 4 February 1952, 1, Digital National Security Archive, accessed 1 August 2014, http://gateway.proquest.com.lumen.cgsccarl.com/ openurl?url_ver=Z39.88-2004\&res_dat=xri:dnsa\&rft_dat=xri:dnsa:article:CIR00274.

123 Ibid. 
also noted that the Tudeh Party strength was estimated much lower than the several hundred thousand claimed by the Tudeh in 1946. The estimated strength was approximately 8,000 active members and as many as 32,000 sympathizers. One concern that the CIA did highlight was the fact that Tudeh Party members had permeated several government agencies, to include the departments of education and justice. ${ }^{124}$

The CIA discussed Iran's traditional policy of balancing the great powers against each other while avoiding political or economic penetration, a theory known as the "Third Force," which was embraced by many developing countries during the Cold War. ${ }^{125}$ The CIA acknowledged that Mosaddeq was as suspicious of the Soviets as he was the British, and that he was becoming increasingly concerned about US interference as well. ${ }^{126}$ Moreover, while the CIA assessed that the Soviets were unlikely to attempt to bolster the Iranian economy significantly, they would therefore "probably estimate that their best chance of gaining control of all or parts of Iran is by allowing the situation to continue to deteriorate.”127

National Intelligence Estimate 46 was a balanced estimate that accurately reflected the interagency intelligence community’s understanding of political, economic, and social forces in Iran at the time. It was a coordinated document that projected moderate outcomes that historical hindsight supports. Interestingly, in a case of foreshadowing, the CIA made an ominous assessment regarding the installment of a new conservative regime:

A conservative regime, however, would be confronted with the same social and economic problems. An attempt by a new government to obtain an oil settlement on terms presently acceptable to the West would meet with the most vigorous opposition by the National Front and the Tudeh Party. Consequently, in order to stay in power and cope with the

${ }^{124}$ Ibid., 2.

${ }^{125}$ Mosaddeq commonly referred to this policy as "negative equilibrium” or "positive neutrality.” For more information about Iranian efforts to balance great powers against each other, see Homa Katouzian, Musaddiq and the Struggle for Power in Iran (London, UK: I.B. Tauris, 1999), 56.

\footnotetext{
${ }^{126}$ National Intelligence Estimate 46, 3.

127 Ibid., 3-4.
} 
situation, such a successor regime would almost certainly be forced to make concessions to national sentiment and rule by authoritarian methods.

This statement implies that the result of an internally (or externally) orchestrated coup would likely be some form of authoritarian rule. The CIA essentially warned the Truman administration that unintended consequences could occur if the US or U.K. attempted to replace the democratically elected prime minister. National Intelligence Estimate 46 indicated that the Truman administration was aware of the ethical dilemma presented by applying covert or conventional military intervention in Iran, and likely considered external interference to be antithetical to US foreign policy objectives.

On November 13, 1952, after the Truman administration exhausted diplomatic efforts to resolve the Iranian Crisis, the CIA produced National Intelligence Estimate 75, entitled "Probable Developments in Iran Through 1953.” National Intelligence Estimate 75 was also a coordinated document, with concurrence from members of the CIA, Department of State, Army, Air Force, Navy, and Joint Staff. The authors of the NIE acknowledged in the opening paragraph that the instability in Iran afforded them very little ability to predict with confidence beyond a short period of time. The CIA assessed that the Tudeh Party was not likely to gain control of the Iranian government via infiltration in 1953, nor was it assessed to be capable of overthrowing the government through force or constitutional means. ${ }^{128}$ However, it contained the following warning:

If present trends in Iran continue unchecked beyond the end of 1953, rising internal tensions and continued deterioration of the economy and of the budgetary position of the government might lead to a breakdown of government authority and open the way for at least a gradual assumption of control by Tudeh. ${ }^{129}$

${ }^{128}$ Central Intelligence Agency. "Probable Developments of Iran Through 1953,” National Intelligence Estimate 75 (13 November 1952), President's Secretary Files, Truman Papers, HSTL, www.trumanlibrary.org, accessed 2 December 2014.

${ }^{129}$ National Intelligence Estimate 75, 6. 
National Intelligence Estimate 75, echoing the same warning included in National Intelligence Estimate 46 regarding the likelihood that a successor regime would resort to authoritarian measures, stated: “Any successor regime would...be likely to resort to ruthlessness to destroy opposition. In its struggle to do so, and particularly if it failed to do so, Tudeh influence and opportunities for gaining control would increase rapidly.” 130 The National Intelligence Estimate authors acknowledged that growing instability in Iran could strengthen Tudeh power. National Intelligence Estimate 75 was cited as a reference to the Truman administration's final policy on Iran, National Security Council Report 136/1.

National Security Council Report 136/1 was published on November 20, 1952, one week after the publication of National Intelligence Estimate 75. While acknowledging that the intelligence community estimated that communist forces would probably not gain control of the Iranian government in 1953, it highlighted the instability in the country and assessed a great threat to the national security of the United States: "If present trends continue unchecked, Iran could be effectively lost to the free world in advance of an actual Communist takeover of the Iranian government." ${ }^{31}$ The policy then outlined a series of measures that the US government must take to prepare for, and prevent, continued instability. These measures included financial aid, technical support, and even the inclusion of Iran in a regional defense arrangement. The inclusion of Iran in a regional defense arrangement represented the first time the US government officially sanctioned a military line of effort to resolve the Iranian Crisis.

${ }^{130}$ Ibid.

${ }^{131}$ National Security Council Report, "United States Policy Regarding the Present Situation in Iran,” Statement of Policy 136/1, 20 November 1952, National Archives and Records Administration (NARA), Record Group 59, "Records Relating to State Department Participation in the Operations Coordinating Board and the National Security Council, 1947-1963," Lot 63D351, National Security Council, Box 68, 2, accessed 14 February 2015, http://www2.gwu.edu/ nsarchiv/NSAEBB/NSAEBB126/. 
In paragraph 5, the policy outlined contingency measures in the event that a communist organization was to seize power in Iran. For the first time, references were made to the use of psychological measures and implementation of “special political operations.” In paragraph 6, a formerly redacted portion of the document, the policy dictates a specific contingency measure employing political operations:

In the event that a communist government achieves complete control of Iran so rapidly that no non-communist Iranian government is available to request assistance, the position of the United States would have to be determined in light of the situation at the time, although politico-military-economic discussions leading to plans for meeting such a situation would be carried on with the British government and with such other governments as may be appropriate. In this contingency, the United States should make every feasible effort, particularly through special political operations, to endeavor to develop or maintain localized centers of resistance and to harass, undermine, and if possible, to bring about the overthrow of the communist government. ${ }^{132}$

From 1950 to 1951, the Truman administration did not consider military intervention or covert actions as courses of action in Iran. Paragraphs 5 and 6 of National Security Council Report 136/1 are evidence of the Truman administration's initial authorization of covert operation planning in Iran in late 1952. Historian Francis Gavin argued the fact that planning for covert operations began during Truman’s presidency represents a major continuity between the two administrations. However, as the following section will demonstrate, a major point of departure between the two presidents was their position with respect to the pre-emptive use of covert operations to disrupt the communist threat. President Truman authorized planning for covert operations only as a contingency in response to a communist coup. ${ }^{133}$

${ }^{132}$ Ibid., 4. Emphasis added.

${ }^{133}$ Historians continue to debate whether Truman's growing concern with respect to Iran indicates that he would have eventually come to the same conclusion as Eisenhower. As Malcolm Byrne acknowledged, “the steady progression of [Truman's] views raises the hypothetical question of whether, had he remained in office for another term, Truman might have eventually followed the same path.” See Malcolm Byrne, "Mohammad Mosaddeq and the 1953 Coup in Iran,” National Security Archive Electronic Briefing Book No. 126, June 22, 2004, accessed 13 February 2015, http://www2.gwu.edu/ nsarchiv/NSAEBB/NSAEBB126/. 
It is important to emphasize that the Truman administration never viewed Mosaddeq as a communist sympathizer. If anything, they feared that his inability to lead effectively could enable communist organizations in Iran, but intelligence estimates downplayed State Department cables that assessed a high potential for a Tudeh takeover. Primarily one individual, Ambassador Loy Henderson, wrote the more alarmist State Department cables. Other State Department officials who interacted with Mossadeq, such as George C. McGhee (Assistant Secretary of State for Near Eastern, South Asian and African Affairs) and Henry F. Grady (the former US Ambassador to Iran) were not as alarmed as Ambassador Henderson. George C. McGhee described his impressions of the premier in an oral history, stating that “Dr. Musaddiq’s background influenced him, on both political and economic grounds, to be a conservative; he had no reason to be attracted to socialism or communism. He was basically, I believe, a patriotic Iranian nationalist, whose lifelong aim was to free Iran from what he perceived to be foreign domination.” ${ }^{134}$ In contrast, Loy Henderson described Mosaddeq’s premiership as “one of the most dangerous kinds of dictatorships. In addition to the street rabble, he had the support of the extreme left, including the Communists and Tudeh Party, extreme Iranian nationalists, some, but not all, of the more fanatical religious leaders, intellectual leftists...” ${ }^{135}$ Loy Henderson retained his position as the Ambassador to Iran during the Eisenhower administration, and was a key player in both the planning and execution of the coup.

The CIA's national intelligence estimates and official memoranda with regard to Iran were well-coordinated and mutually supportive assessments that reflected close interagency cooperation during the Truman administration. More importantly, they also appear to have informed and influenced policymaking. Official memoranda, approved and released by the Office

${ }^{134}$ George C. McGhee, "Recollections of Dr. Muhammad Musaddiq,” in James A Bill and William Roger Louis, eds., Mussadiq, Iranian Nationalism, and Oil (Austin, TX: University of Texas Press, 1988), 302.

${ }^{135}$ Loy Henderson, Eisenhower Administration Oral History Project, Columbia University Rare Books and Manuscript Library, 1970, 9. 
of National Estimates, were used to inform top decision-makers during crises, and formal, coordinated national intelligence estimates were nested in both National Security Council Policy Reports on US policy towards Iran. The documents produced by the CIA’s Office of National Estimates captured the complexity of the evolving situation in Iran while also carefully identifying the risks of US intervention. The Office of National Estimates therefore effectively influenced the Truman administration during the Anglo-Iranian Oil Crisis. As the next section will show, this influence was lost during the planning stages of Operation AJAX under the Eisenhower administration. 


\section{Section Five}

\section{The Eisenhower Administration's Policy Toward Iran}

The presence of Allen Dulles as head of the CIA was a sign of how close covert operations and intelligence were to Eisenhower's heart. Never before and never since have there been such close links between the White House, the State Department, and the CIA.

\section{—Zachary Karabell, Architects of Intervention}

President Eisenhower took office in January 1953. He was elected on a mandate that called for a tough stance against communism in the wake of the PRC's communist revolution and the Korean War. Eisenhower nominated John Foster Dulles to serve as the Secretary of State and Charles Wilson served as the Secretary of Defense. Allen Dulles was elevated to the position of Director of Central Intelligence and Walter Bedell “Beedle” Smith, the former Director of Central Intelligence, was relocated to the State Department where he served as the Under Secretary of State, strongly strengthening ties between the CIA and State Department.

After his inauguration, President Eisenhower immediately implemented his New Look Policy, which sought to combat the communist threat while also balancing the US budget by reducing military spending. John Foster Dulles was selected to serve as Secretary of State largely because of his support for the New Look Policy. ${ }^{136}$ Domestic events in Iran had taken a precipitous downturn in the months coinciding with Eisenhower's inauguration, largely as a result of Britain’s boycott of Iranian petroleum products. A partially declassified CIA history of Operation Ajax described the political context in the wake of World War II:

TPAJAX came at a time when the events in pre-war Europe were a fresh memory. Americans had seen how Nazi subversion could destroy a country like Czechoslovakia. They had seen the consequences of weakness and appeasement before Nazi and Japanese demands. They had suffered the incalculable cost of failing to act when action might have

136 John Lewis Gaddis, Strategies of Containment (New York, NY: Oxford University Press, 1982). 
stopped further aggression. Many were determined never again to let the appearance of weakness and indecision encourage aggression. ${ }^{137}$

Prior to Eisenhower's inauguration, the British government's lead intelligence agency, the Secret Intelligence Service (SIS), was already working in tandem with US CIA operatives to plan covert operations in Iran. The SIS station chief, Christopher "Monty” Woodhouse, at the suggestion of two leading British academics on Persian affairs (Ann Lambton of London University and Robin Zaehner of Oxford), approached the CIA with a draft plan for a coup codenamed Operation Boot. ${ }^{138}$ The newly re-elected British Prime Minister, Winston Churchill, a close friend and ally of President Eisenhower's, was supportive of the planning effort. ${ }^{139}$

In his memoir, Something Ventured, Woodhouse described the Dulles brothers when he wrote "a power leverage on US foreign policy was available there [in the Eisenhower administration], if I could influence CIA.” ${ }^{140}$ In mid-November, Woodhouse travelled to Washington to discuss the planning effort with US decision-makers. There he was met with “Beedle” Smith and various State Department officials who initially expressed skepticism. In an ominously accurate prediction, Woodhouse quoted Smith as saying, "You may be able to throw out Musaddiq, but you will never get your own man to stick in his place.” ${ }^{141}$ Woodhouse also stated that the State Department under the Truman administration was open to planning for covert

${ }^{137}$ Scott A. Koch, “Zendebad, Shah!”: The Central Intelligence Agency and the Fall of Iranian Prime Minister Mohammed Mossadeq, August 1953, Central Intelligence Agency History, June 1998. Accessed 1 August 2014, http://www2.gwu.edu/ nsarchiv/NSAEBB /NSAEBB435/.

${ }^{138}$ Hugh Wilford, America's Great Game: The CIA's Secret Arabists and the Shaping of the Modern Middle East (New York, NY: Basic Books, 2013), 163. Operation Boot was eventually incorporated into Operation Ajax, the American name for the coup.

${ }^{139}$ For more on the British perspective of the planning effort, see Woodhouse's memoir. C. M. Woodhouse, Something Ventured (London, UK: Granada, 1982).

${ }^{140}$ Woodhouse, 117.

${ }^{141}$ Ibid., 118. This comment is interesting, because Roosevelt recounted that Smith ultimately supported the execution of the coup. 
operations, but they were "still hankering after the less bold of the two possible course: the prevention of a Communist coup without overthrowing Musaddiq—indeed, with his participation—rather than by overthrowing Musaddiq." ${ }^{142}$ Woodhouse therefore over emphasized the communist threat to Iran (rather than nationalist ambitions that threatened British economic interests) in order to garner US support for the coup.

Beginning in 1953, a marked change in the tone of the assessments by both the CIA and the National Security Council is observed. The change in tone was likely due to a combination of factors: A political crisis erupted in Iran in February 1953 when the Shah attempted to flee the country, Eisenhower began implementing his New Look Policy, and the CIA and Secretary of State cabinet positions had been recently shuffled after President Eisenhower's inauguration. After Allen Dulles assumed the Director of Central Intelligence position, an increased emphasis and interest in covert capabilities was observed. In a biography about Allen Dulles, historian James Srodes described Dulles’ penchant for covert operations: “Dulles had organized the agency so that every important job was the responsibility of somebody other than himself. The genius of that arrangement was that it left him free to be involved in the covert operations side of the agency — the side that most interested the president and Foster, the side where the quickest results could be enjoyed, and side where the biggest risks of disaster lurked.”143

On 1 March 1953, the CIA published a memorandum for the President that was more alarmist than previous assessments from the Truman administration:

Ever since the assassination of General Razmara in March 1951, and the subsequent impasse and diplomatic break with Britain over the oil negotiations, the Iranian situation has been slowly disintegrating. The result has been a steady decrease in the power and influence of the Western democracies and the building up of a situation where a Communist takeover is become more and more of a possibility. ${ }^{144}$

142 Ibid., 122.

143 James Srodes, Allen Dulles (Washington, DC: Regnery, 1999), 465. See also Peter Grose, Gentleman Spy (Boston, MA: Houghton Mifflin, 1994).

${ }^{144}$ Central Intelligence Agency, Memorandum for the President of the United States, “The Iranian Situation,” 1 March 1953, NSC Staff Paper, Box 65, Disaster File, Iran (3), DDEL. 
The memorandum for the President stated, "significant elements of the Army will probably remain loyal to the Shah, but whether or not they can be forged into an effective weapon in shaping political developments depends on the Shah's determination to use them.” ${ }^{145}$ The author concludes that "the present situation offers the Shah an opportunity which he has not yet seized," hinting at the potential for the Shah to coalesce power around the monarchy. ${ }^{146}$ Based on the timing and contents of the assessment, it may have served as a point paper to inform the president's decision to authorize the use of covert force. ${ }^{147}$

Four days later, during the $135^{\text {th }}$ Meeting of the National Security Council, Allen Dulles was asked to brief the council on recent developments in Iran. Mr. Dulles presented a very severe assessment:

The probable consequences of the events of the last few days, concluded Mr. Dulles, would be a dictatorship in Iran under Mossadegh. As long as the latter lives there was but little danger, but if he were to be assassinated or otherwise to disappear from power, a political vacuum would occur in Iran and the Communists might easily take over. The consequences of such a take-over were then outlined in all their seriousness by Mr. Dulles. Not only would the free world be deprived of the enormous assets represented by Iranian oil production and reserves, but the Russians would secure these assets and thus hence-forth be free of any anxiety about their petroleum situation. Worse still, Mr. Dulles pointed out, if Iran succumbed to the Communists there was little doubt that in short order the other areas of the Middle East, with some $60 \%$ of the world's oil reserves, would fall into Communist control. ${ }^{148}$

${ }^{145}$ Ibid.
146 Ibid.

${ }^{147}$ Interestingly, underneath the CIA's letterhead, a subheading with the words "Office of National Estimates" is crossed out. This implies that the Office of National Estimates was not involved in the production of the document. An approving authority's name also does not appear on the memorandum, in sharp contrast to the two official memorandums referenced in Section 4, which were signed by William Langer and Paul Borel as representatives of the Office of National Estimates. The tone of the document is also less formal than the two previous CIA memorandums and hints at familiarity, as evidenced by the author's reference to the US Ambassador to Iran as "Henderson." William Langer, the author of the "Harriman Mission" memorandum referred to Ambassador Harriman as "Averell Harriman," reflecting the appropriate professional deference to a diplomat. Although completely speculative, it is quite possible that Allen Dulles coordinated, or even drafted, the document himself.

$148135^{\text {th }}$ Meeting of the National Security Council, 4 March 1953, Ann Whitman Files, Box 4, NSC Series, DDEL. 
At this point, Secretary John Foster Dulles presented three potential courses of action (COA) in Iran: 1) Recall Ambassador Henderson, 2) Disassociate from the British government in order to preserve the United States’ reputation with Iran, or 3) Purchase oil from the National Iranian Oil Company and provide technical support to the oil refinery in order to prop up the Iranian economy. ${ }^{149}$ Secretary Dulles then lamented that he did not find any of the courses of action suitable due to concerns about losing British support in combatting communism in other parts of the world. General Vandenberg from the Joint Chiefs of Staff presented a fourth COA, the deployment of US forces along the Zagros Mountain Range in Southern Iran, which would have required the reallocation of forces already committed to the Korean Peninsula. ${ }^{150}$

When asked by a National Security Council member whether Secretary Dulles was already convinced that Russia would ultimately secure Iran if no action were taken, John Foster Dulles replied in the affirmative, indicating that both Dulles brothers shared an alarmist perspective. ${ }^{151}$ The National Security Council proceeded to discuss the prospects of seeking a unilateral negotiation with Iran with British consent, the use of force to defend Iran, and the opportunities presented by Stalin’s illness. ${ }^{152}$

It is estimated that sometime in March 1953 President Eisenhower informally authorized the execution of Operation Ajax. ${ }^{153}$ On March 20, 1953, the Department of State published a

\footnotetext{
149 Ibid., 6-7.

150 Ibid., 9.

${ }^{151}$ Ibid., 8.
}

${ }^{152}$ Stalin died the next day on March 5, 1953. Mosaddeq speculated in his memoir that Stalin's death removed barriers that had until then prevented the U.S. from considering the use of military force in Iran. See Mohammad Musaddiq and Homa Katouzian, Musaddiq's Memoirs (London, UK: JEBHE, National Movement of Iran, 1988), 272.

153 Malcolm Byrne and Mark J Gasiorowski, Mohammad Mosaddeq and the 1953 Coup in Iran (Washington, DC: National Security Archive, 2004), xiv. The CIA internal history, Battle for Iran, states that final formal approval came on July 11, 1953. 
memorandum for the National Security Council entitled "First Progress Report on Paragraph 5-a of NSC 136/1.” The First Progress Report marks a significant divergence between the Truman and Eisenhower administrations: the willingness to conduct covert operations pre-emptively.

There is also the possibility that a communist seizure of power in Iran may take place imperceptibly over a considerable period of time. Under this contingency, it would be extremely difficult to identify and demonstrate to our allies that specific countermeasures were required to prevent communist infiltration from reaching the point where it would be able to significantly influence the policies of the Iranian government. In such circumstances, it might be desirable to implement certain of the plans discussed in the attached report, prior to identifiable attempted or actual communist seizure of power. ${ }^{154}$

The Iranian Crisis was discussed briefly at the $136^{\text {th }}$ National Security Council Meeting on March 11, 1953, but no reference was made to use of conventional military or covert actions to resolve the crisis. Iran was not discussed at the National Security Council again until the $160^{\text {th }}$ Meeting on August 27, 1953, several days after the coup had concluded. The remaining historical record of the Eisenhower administration's decision-making process is sparse due to the highly secretive nature of the planning effort. Indeed, many State Department officials and CIA analysts at the time were unaware of the plan. The recently re-released CIA history, Battle for Iran, describes a State Department memorandum dated June 10, 1953, in which an official—clearly unaware of the ongoing planning effort-recommended financial aid to Iran, at the expense of British loyalty. The author argued, "since an attempt to remove Mosadeq would risk a civil war and would, even if successful, alienate the Iranian people, we should increase our financial and technical assistance to Iran.” ${ }^{155}$ The history states that some additional State Department officials did learn about the plan by mid-June and were able to review the plan. However, in a formally

${ }^{154}$ US Department of State. "First Progress Report on Paragraph 5-1 of NSC 136/1, 'U.S. Policy Regarding the Present Situation in Iran,” 20 March 1953, National Archives and Records Administration (NARA), Record Group 59, "Records relating to State Department Participation in the Operations Coordinating Board and the National Security Council, 1947-1963," Lot 63D351, National Security Council, Box 68, ccessed 14 February 2015, http://www2.gwu.edu/ nsarchiv/ NSAEBB/NSAEBB126/. Emphasis added.

155 Battle for Iran, 31. 
redacted portion of the document, a footnote states, “no formal estimates as to the potential for success of the coup were prepared by ONE [Office of National Estimates], although that office was producing special estimates on the situation in Iran.” ${ }^{156}$ This footnote clearly indicates that the Office of National Estimates was either marginalized or completely excluded from the planning process for Operation Ajax.

In Countercoup, Roosevelt's description of his initial pre-decisional brief of Operation Ajax plan to Secretary John Foster Dulles provides some useful insight into the Dulles brothers' decision-making processes. It highlights their proclivity to surround themselves with like-minded individuals, silence dissenting opinions, and exclude senior intelligence analysts from discussions of US foreign policy when their assessments did not support their preferred course of action:

Inside JFD’s [John Foster Dulles] office an impressive assembly was already gathered...in respectful silence, to give their serious consideration to our proposal.

At least so it seemed. I soon realized that most of the group had already concluded that anything but assent would be ill-received by its chairman. If "serious consideration" did not lead to approval, it would best be forgotten. ${ }^{157}$

Roosevelt listed a number of officials that attended the meeting, including cabinet officials, various diplomats and lawyers. One of the most prominent participants was Loy Henderson, the vocal ambassador to Iran whom Roosevelt described as being "most influential in that decision.” There were no representatives from the Office of National Estimates mentioned in Roosevelt's memoir. Roosevelt recalled that when Allen Dulles was asked for his opinion, he merely acknowledged that there were inherent risks to the operation, but that he felt that proper planning had been conducted to mitigate those risks. ${ }^{158}$ Roosevelt later admitted in an interview that in late 1952, when British agents proposed Operation Boot, he and Allen Dulles (then appointed to

${ }^{156}$ Ibid., 38. Interestingly, the majority of Section III of the Battle for Iran, which details the planning stages of Operation Ajax, was only recently declassified in June of 2014.

${ }^{157}$ Roosevelt, 3-4.

158 Ibid., 17. 
assume the position of the Director of Central Intelligence) "were in quiet disagreement with the outgoing administration's positions and had in fact already begun studying possible action in support of the Shah..." ${ }^{159}$ If true, Roosevelt's recollections indicate that Allen Dulles had a penchant for direct involvement in policymaking beyond merely advising.

In conclusion, the Eisenhower administration, under the leadership of John Foster Dulles and Allen Dulles, marginalized and excluded the Office of National Estimates from the decisionmaking processes of Operation Ajax. Estimates by the British government and the Dulles Brothers exaggerated the crisis in Iran in order to align US policy with political agendas. The planning for Operation Ajax is therefore a quintessential example of analyst-policymaker tensions, a phenomenon that will be discussed in the following section.

${ }^{159}$ As quoted in Wilford, 164. 


\section{Conclusion}

Almost any man or group of men confronted with the duty of getting something planned or getting something done will sooner or later hit upon what they consider a single most desirable course of action. Usually it is sooner; sometimes, under duress, it is a snap judgment off the top of the head. The way in which such people arrive at this most desirable course of action does not require them to examine all the facts critically and dispassionately and to arrange them into logically sound and secure pattern. They may arrive at their solution in ignorance of many relevant and important facts, and with their prejudices and clichés of thought discriminating in favor of the facts which they do use. This kind of off-the-cuff solution tends to harden into what I have termed policy.

—Sherman Kent, Strategic Intelligence for World Policy

Since 2001, a multitude of studies have been published regarding the endemic faults of the intelligence community that contributed to the strategic surprise of 9/11. Many of these studies have also examined historic intelligence failures, to include the attack on Pearl Harbor, the Cuban Missile Crisis, the Iranian Revolution, and the Terrorist Attacks on September 11, 2001. Some recent studies have also identified the 2002 National Intelligence Estimate on the Iraq Weapons of Mass Destruction Program as an example of an intelligence failure, not because of strategic surprise, but because flawed analysis was used to justify the decision to commit troops to Iraq. ${ }^{160}$ Despite the controversy surrounding it, Operation Ajax is not commonly referred to as an intelligence failure. This is likely due to the fact that the intelligence provided by the Directorate of Intelligence, the analytic branch of the CIA, accurately reflected the community's understanding (or lack of understanding) of the situation in Iran. However, an analysis of the policies and estimates surrounding the coup indicates that flaws in the CIA's structure may have reduced the influence that the analytic branch of the CIA had on policymaking decisions during the Eisenhower administration.

In Why Intelligence Fails, Robert Jervis identified and described several common intelligence analytical failures that are frequently attributed to flawed intelligence estimates.

${ }^{160}$ For a sample of these “post-mortems,” see Jervis, Why Intelligence Fails (2010); Fingar; Jones and Silberzahn. 
These include expressions of excessive certainty, "groupthink," politicization, and confirmation bias. There is evidence to suggest that each of these analytical mistakes was made in the decision to intervene in Iran in 1953, however, many of the mistakes were made by policymakers rather than by intelligence analysts. More disturbingly, the mistakes were made despite the availability of the highly qualified and effective Office of National Estimates within the Directorate of Intelligence. The analytical mistakes likely occurred because of tensions between analysts and policymakers that were exacerbated by the structural organization of the CIA.

In its formative years the CIA was really two organizations within one: a Directorate of Operations, a clandestine service which collected intelligence and conducted covert operations; and a Directorate of Intelligence, an analytic/coordinating service that coordinated intelligence from the interagency and developed intelligence estimates. ${ }^{161}$ Both organizations reported to the Director of Central Intelligence, who reported directly to the National Security Council and the President. At that time, the CIA was headed by a series of leaders who each had a preference for the covert wing side of the CIA, to include William Donovan, Walter Bedell Smith, and Allen Dulles. Despite the fact that the CIA was never specifically mandated to conduct covert operations, vague language within the 1947 National Security Act, coupled with Cold War prerogatives and rivalries within the interagency intelligence community, provided an opportunity and justification for the founders of the CIA to strengthen the covert side of the CIA at the expense of its analytical wing. As Amy Zegart argued, the CIA’s structure is significant because many of the CIA's struggles appear to be related to organizational flaws, which in turn have contributed to flawed policy outputs. ${ }^{162}$ This hypothesis is further supported by the fact that President Eisenhower ordered an external study of the CIA and its operations in 1954. Known as

\footnotetext{
161 The Office of National Estimates resides within the Directorate of Intelligence. 162 Zegart, 1-3.
} 
the Doolittle Report, the investigator, Lt. Gen. James Doolittle (USAF) reported his observation that "the weakness of the CIA is in the organization-it grew like topsy [sic], sloppy organization.”163

It must next be established that Allen Dulles’ role in the decision-making process was that of a policymaker, not as an analyst. Allen Dulles' preference for operations over analysis, his close relationship to his brother, the Secretary of State, and his proximity to the Oval Office encouraged his active participation in the policymaking process, even though his position mandated that he remain an impartial advisor to the president of both intelligence estimates and covert capabilities. As evidenced by his comments in the $135^{\text {th }}$ National Security Council Meeting, Allen Dulles did not represent the best estimates of the intelligence community. Rather, what were likely his personal judgments regarding the situation in Iran and the potential for covert operations superseded the nuanced assessments previously written by the Office of National Estimates. Indeed, Dulles never tasked the Office of National Estimates with evaluating the likelihood of success of covert operations in Iran, a mistake he repeated eight years later during the Bay of Pigs disaster, and which ultimately led to his resignation. ${ }^{164}$ In short, due to his own predilections towards covert operations, Allen Dulles did not adequately represent the full authority or capability of the CIA.

The majority of intelligence estimates produced during the Iranian Crisis reflected appropriate levels of certainty. Whereas Allen Dulles characterized the likelihood of the Iranian government to collapse into a dictatorship as probable at the $135^{\text {th }}$ National Security Council

${ }^{163}$ Notes of Report Debriefing, Lt. General (Ret.) James H. Doolittle to Dwight D. Eisenhower, Ann Whitman File, Administration Series, Box 13. 19 October 1954, DDEL. The actual report compiled by Lt. General (Ret.) Doolittle could not be found at the Dwight D. Eisenhower Presidential Library, likely due to the classified nature of its contents. However multiple memorandums document its existence. For an example, see Dwight D. Eisenhower to Lt. Gen. (Ret.) James H. Doolittle, "Panel of Consultants on Covert Activities of the Central Intelligence Agency,” Ann Whitman File, Administration Series, Box 13. 26 July 1954. DDEL.

${ }^{164}$ Irving L. Janis, Groupthink (Boston, MA: Houghton Mifflin, 1982), 24. 
Meeting, the intelligence community merely assessed that a government collapse might occur in National Intelligence Estimate 75. And while the CIA's Office of National Estimates assessed that a government collapse could lead to a gradual assumption of control by the Tudeh Party, they assessed that such an outcome was not likely to occur in 1953. A prominent Cold War historian, Bruce Kuniholm, alleged that the problem was not simply a poor choice of wording but instead reflected a deliberate misrepresentation of the threat:

The United States had penetrated the Tudeh, was intercepting its orders, and was in a position to know that there was little threat. This made no difference at the highest levels of the CIA and State Department (i.e., Allen and John Foster Dulles)... [The CIA] overstated the threats posed to national-security interests in an effort to carry out the policies of the Dulles brothers. ${ }^{165}$

As a result, the analysis expressed during the $135^{\text {th }}$ National Security Council Meeting did not reflect the graduated alternatives that were considered during the Truman administration. Allen Dulles essentially employed a slippery slope fallacy in which he outlined a chain of consequences that linked governmental collapse in Iran to an eventual Communist takeover of the entire Middle East. The Office of National Estimates never directly linked the growth of the Tudeh Party to the eventual consolidation of Soviet control over the Middle East. While National Security Council Paper 136/1 under the Truman administration did call for the planning of courses of action that would include military intervention and covert "political” operations, they were considered contingencies that would be employed "in light of the situation of the time.” A communist takeover was not treated as a foregone conclusion, and the Truman administration felt that military intervention should occur only after a communist coup had occurred.

John Kotter theorized in his book, Power and Influence, that diversity of opinion and interdependence tend to foster critical thinking and good decision-making. ${ }^{166}$ Lack of diversity

${ }^{165}$ Kuniholm, 435. For a similar argument, see Stephen Kinzer, All the Shah's Men, (Hoboken, NJ: J. Wiley \& Sons, 2003).

166 John P. Kotter, Power and Influence (New York, NY: Free Press, 1985). 
and poor interdependence between group members tend to promote intellectual conformity. Milo Jones and Philippe Silberzahn came to similar conclusions using a social constructivist approach in their book, Constructing Cassandra. Jones and Silberzahn argued that intelligence analysis is an inherently social process and the processes of analyzing competing hypotheses and coordinating intelligence estimates are examples of the social nature of intelligence. ${ }^{167}$ A lack of cultural diversity within an intelligence organization can impede critical analytic techniques. By extension, a lack of diversity among leading policymakers likely impeded the Eisenhower administration's decision-making processes. The fact that Secretary of State and Director of Central Intelligence were brothers indicates that the already small group of influential policymakers involved in the planning of Operation Ajax probably shared similar ideologies and biases. In his report, Lt. Gen. (Ret.) Doolittle also observed that Allen Dulles had a tendency to surround himself with people chosen more for loyalty than for competence, which was compounded by his close ties to his brother. ${ }^{168}$ Another study, known as the Bruce-Lovett Report, reported similar findings in 1957: “At times, the Secretary of State/DCI brother relationship may arbitrarily set 'the US position."”169 The Dulles brothers appeared to have unbalanced influence over US foreign policy.

${ }^{167}$ For more on socio-cultural studies of the intelligence community, see Richard J. Heuer, Psychology of Intelligence Analysis (Washington, DC: Center for the Study of Intelligence, Central Intelligence Agency, 1999); Jeffrey R. Cooper, Curing Analytic Pathologies (Washington, DC: Center for the Study of Intelligence, 2005); Rob Johnston, Analytic Culture in the US Intelligence Community (Washington, DC: Center for the Study of Intelligence, Central Intelligence Agency, 2005); and Roger Z. George and James B. Bruce, Analyzing Intelligence (Washington, DC: Georgetown University, 2008).

${ }^{168}$ Doolittle, 1. Eisenhower ultimately rejected this conclusion, arguing that the closeness between the two brothers helped safeguard secrets. 447.

${ }^{169}$ As quoted in Peter Grose, Gentleman Spy (Boston, MA: Houghton Mifflin, 1994), 
Irving Janis, arguably the leading scholar of the phenomenon known as "groupthink,” observed that groupthink tends to correlate with major defects in decision-making. ${ }^{170}$ These defects include the failure to consider alternative courses of action, failure to survey values and risks, little or no effort to obtain information from experts, and selective bias that ignores opinions or facts that counter group norms. According to Kermit Roosevelt’s memoir, and supported by an analysis of primary source documents, all of these defects were present during the Operation Ajax decision-making processes. Janis listed a series of groupthink "fiascoes" (i.e. policymaking disasters) to include the Bay of Pigs Disaster and Pearl Harbor. The decision to execute Operation Ajax was also a severe case of groupthink, however unlike the Bay of Pigs and Pearl Harbor, the unanticipated and undesired second and third order effects were not fully appreciated until decades later.

Perhaps due to the small group dynamics already discussed (groupthink, confirmation bias, lack of diversity, etc.), the Eisenhower administration rejected, minimized or omitted alternative assessments produced by the Office of National Estimates. Several theories regarding the impact that structures and institutions have on the influence of intelligence analysis support this conclusion. Sherman Kent first described the phenomenon of analyst-policymaker tensions in the 1960s, and political scientist Robert Jervis expanded Kent’s theory by studying recent intelligence failures. Jervis argued that analysts and policymakers frequently clash when intelligence assessments do not promote a policymaker’s agenda. ${ }^{171}$ Policymakers must “sell” their policy to the public so they frequently seek backing from the intelligence community. Intelligence analysts are responsible for informing policymakers in an unbiased manner that will promote better policy, often by identifying hidden costs or dangers inherent to a proposed policy.

170 Janis, 10.

${ }^{171}$ Robert Jervis, “Why Intelligence Analysts and Policymakers Clash,” Political Science Quarterly 125, no. 2 (2010): 187. 
Policymakers, however, prefer that analysts promote and reinforce their already existing policies, sometimes at the expense of accuracy. When analytical assessments do not match a policymaker's perception of the situation, the policymaker is prone to suspect political bias or flawed analysis on the part of the analyst. ${ }^{172}$

Complex problems, such as understanding social dynamics within a foreign country, are likely to garner nuanced assessments from the intelligence community that include weak confidence levels and an identification of intelligence gaps and shortfalls. However, confidence and simplicity are needed to bolster a policy, whereas ambiguity or complexity tends to weaken a policy position. When a low confidence level or a difference of opinion threatens a policy, a policymaker may be tempted to influence the analyst to change his or her assessment in view of political considerations. ${ }^{173}$ This is a problem known as the "politicization of intelligence.” When this occurs, policymakers may manipulate the "bar of proof regarding judgments" in order to preserve their agendas. ${ }^{174}$ The CIA Memorandum to the President, dated 1 March 1953, is likely an example of a politicized estimate. "Politicization by omission,” a tendency explored by John A. Gentry, occurs when an analyst or manager avoids issues or omits data that will offend political officials. ${ }^{175}$ The absence of representatives from the Office of National Estimates at key decision-making meetings and the lack of a formal national intelligence estimate on the feasibility of covert operations in Iran are likely attributable to politicization by omission.

172 Jack Davis, "Intelligence Analysts and Policymakers: Benefits and Dangers of Tensions in Relationship,” Intelligence and National Security 21, no. 6 (2006): 1002.

173 Jervis, 189.

${ }^{174}$ Davis, 1004. Alternatively, as Davis noted, when an analyst receives criticism from a policy official on a particular assessment, they are likely to suspect politicization, as opposed to honest and appropriate feedback.

175 John A. Gentry, Lost Promise: How CIA Analysis Misserve the Nation (Lanham, MD: University Press of America, 1993). 
Social scientist Catherine Tinsley studied intergroup dynamics as an aspect of organizational life within the intelligence community. She argued that social groups exist in all organizations, and that they have a predisposition to create "cognitive roadblocks" to cooperation and collaboration. ${ }^{176}$ These are frequently due to misaligned organizational incentives and conflicting political pressures. She concludes that these roadblocks are not unique to the intelligence community, but are fundamental to organizational life, and that deliberate efforts must be made to overcome them. Organizational structure can exacerbate or prevent these roadblocks by improving trust and integration. As evidenced by the national intelligence estimates produced during the Anglo-Iranian Oil Crisis, the Office of National Estimates contributed to, and influenced, the policymaking decisions that were made during the Truman administration. Cognitive roadblocks, such as the exclusive and secret nature of covert operations planning, combined with the small group dynamics of the Eisenhower decision-making circle, likely reduced the influence of those valuable intelligence estimates. Certainly, the classified nature of covert operations has reduced the public's access to evidence that would confirm of deny this hypothesis.

A review of the historical record indicates that the founders of the intelligence community were aware of many of the potential hazards to effective intelligence estimating from the very creation of the CIA and attempted to build systems to improve analytic processes and procedures. The federation of the intelligence community by William Donovan, the creation of a coordinating review process by the JIC, and the multiple publications written by members of the Office of National Estimates indicate that coordination is critical for the avoidance of groupthink, bias, and faulty analysis. In the 1950s, the CIA was still a homogenous organization that suffered

${ }^{176}$ Christine Tinsley, “Social Categorization and Intergroup Dynamics,” in Intelligence Analysis: Behavioral and Social Scientific Foundations, Baruch Fischhoff and Cherie Chauvin (Washington, DC: National Academies Press, 2011), 197-217. 
from a lack of diversity, but its founding members attempted to mitigate those shortcomings with institutional initiatives within the interagency.

Efforts by leading analysts such as Sherman Kent, William Langer and Ray Cline to accurately inform and influence policy were neutralized by both organizational and social phenomena. In addition to the theories already described, this monograph postulates that the bifurcated structure of the CIA, which separated the analytical branch from the covert operations branch, exacerbated analyst-policymaker tensions as it created a conflict of interest for the Director of Central Intelligence: The same individual who was responsible for showcasing covert capabilities was also responsible for advising the president on intelligence estimates that might recommend against the use of those capabilities. This bifurcation encouraged directors to place a priority on covert operations over analysis. Had the Office of National Estimates been in a completely separate agency from the covert operations branch, with equal representation at key policymaking deliberations, some of these analytical mistakes might have been avoided.

Biases among policymakers and analysts were evident in both the Truman and Eisenhower administrations, but the CIA's structural flaws became more apparent during the Eisenhower administration. The secretive nature of covert operations reduced the analytic filters afforded by coordination and instead amplified the alarmist viewpoints of several leading policymakers, to include Ambassador Loy Henderson, Secretary John Foster Dulles, and Director of Central Intelligence Allen Dulles. The processes and procedures built by the founders of strategic intelligence analysis to reduce groupthink and bias were removed during the planning of covert operations, thus a small homogenous group of men with similar biases and ideologies were able to give unchallenged advice to the President on a critical foreign policy decision.

An ideal policy is one that meets many goals, is supported by multiple considerations, and has few costs. ${ }^{177}$ When weighing the potential policy solutions for the Anglo-Iranian Oil

\footnotetext{
177 Kent, 188.
} 
Crisis, President Eisenhower viewed covert action as the policy that best met those criteria. The use of ground forces while the Korean War was ongoing would have been too costly.

Abandonment of a critical wartime ally, the British, was viewed as politically unsuitable. The rampant fear of the spread of communism bolstered the legitimacy of the action. Covert action appeared at the time to be the perfect solution to a complex problem. As historian Douglas Little noted:

Ever since Franklin Roosevelt asked Wild Bill Donovan to establish the OSS in 1941, America's leaders have consistently assumed that plausibly deniable clandestine operations constitute a quick and cheap way to protect US interests and to promote US objectives in the Middle East without running the risk of lengthy and costly military intervention. ${ }^{178}$

However, an estimate of the likelihood of success, both short-term and long-term, by the CIA's Office of National Estimates could have aided presidential decision-making. The Eisenhower administration did not carefully consider the long-term second and third order effects of a coup. Primary source documents indicate that members of both the Office of National Estimates recognized early on that removing Prime Minister Mosaddeq would likely result in some form of arbitrary authoritarian rule, however they did not estimate that it would be the Shah himself who would consolidate that rule. While it can never be determined whether the Office of National Estimates could have altered the course of events had it been included in the decision-making process, hindsight shows us that the Eisenhower administration's decision-making processes during the Anglo-Iranian Oil Crisis were deeply flawed. The structural organization of the CIA, the small-group dynamics of Eisenhower's inner circle, and a tense analyst-policymaker relationship between the interagency intelligence community and the Dulles Brothers, reduced the influence and effectiveness of a talented group of intelligence analysts who could have improved the policy-making process.

${ }^{178}$ Douglas Little, "Mission Impossible: The CIA and the Cult of Covert Action in the Middle East,” Diplomatic History 28, no. 5 (2004): 663-701. 
The Central Intelligence Agency, as well as the broader interagency intelligence community, is currently implementing many new reforms in order to prevent analytic failures. ${ }^{179}$ The continued study of historical intelligence procedures will aid the intelligence community in developing structures and processes that will improve accuracy and influence. This analysis of Operation Ajax argues that organizational structure impeded the effectiveness of intelligence analysis in influencing policy. The CIA's structure in 1953 maximized the influence of its covert operations branch at the expense of its analytical branch. The two functions must be separate but have equal representation at policy deliberations in order to combat inherent analyst-policymaker tensions. Moreover, organizational processes must be maintained to encourage collaboration and trust between analysts, operators, and policymakers. A broader study of the role that organizational structure had on the efficacy of all historic intelligence estimates is needed in order to inform the current restructuring of intelligence agencies.

A second potential area for future study is a closer examination of the efficacy of intelligence estimation in anticipating the unintended consequences of proposed policies, particularly with relation to covert activities. Ray Cline made this argument in 1980 (shortly after the CIA failed to predict the 1978 Iranian Revolution) when he wrote, “the work of drafting national estimates on strategic situations and the probable consequences of various options in US policy ought to be a first-priority task for CIA. It need not be a clandestine activity.”180 The secret close-hold nature of covert operations planning exacerbated small group dynamics that promoted groupthink, bias and conformity. While intelligence estimating will never be

${ }^{179}$ For more on ongoing reforms in the interagency intelligence community, see Richard Immerman's article on Analytic Transformation and the creation of the Office of the Director of National Intelligence: Richard Immerman, “Transforming Analysis: The Intelligence Community's Best Kept Secret,” Intelligence and National Security 26, no. 2-3 (2011): 159-181.

${ }^{180}$ Ray Cline, “The Future of U.S. Foreign Intelligence Operations,” in The United States in the 1980s, eds. Peter Duignan and Alvin Rabushka (Stanford, CA: Hoover Institution, Stanford University, 1980), 478. 
completely objective and is subject to its own analytical constraints, the participation of intelligence analysts in policymaking decisions decreases the likelihood that groupthink will occur and can aid in the anticipation of long-term second and third order effects.

As a concluding point, the declassification of historical intelligence records aids in the ongoing development of the intelligence analytical discipline. Social science theories provide a useful lens through which to analyze historical intelligence case studies for the continued improvement of the profession and its organizations. The interagency intelligence community has existed for less than one hundred years. Greater transparency through the declassification of historical documents is needed for effective evaluation and study. 


\section{Bibliography}

\section{Archival Materials}

The Central Intelligence Agency Freedom of Information Act Electronic Reading Room

Donovan, William. “Donovan Memorandum to the President.” Memorandum for the President of the United States. 26 December 1944. Creating Global Intelligence Collection. The Central Intelligence Agency Freedom of Information Act Electronic Reading Room. Accessed 15 January 2015. http://www.cia.foia.gov.

. "The Basis for a Permanent United States Foreign Intelligence Service.” Memorandum for the President of the United States. 10 October 1944. Creating Global Intelligence Collection. The Central Intelligence Agency Freedom of Information Act Electronic Reading Room. Accessed 15 January 2015. http://www.cia.foia.gov.

. "The Donovan Plan for the Establishment of a Central Intelligence Authority." Memorandum for the President of the United States. 18 November 1944. Creating Global Intelligence Collection. The Central Intelligence Agency Freedom of Information Act Electronic Reading Room. Accessed 15 January 2015. http://www.cia.foia.gov.

"Report By The Joint Strategic Survey Committee To The JCS On JCS 1181 And JIC 239/5.” Report. 24 January 1945. Creating Global Intelligence Collection. The Central Intelligence Agency Freedom of Information Act Electronic Reading Room. Accessed 15 January 2015. http://www.cia.foia.gov.

\section{Columbia University Rare Books and Manuscript Library}

Henderson, Loy. Oral History Interview. Eisenhower Administration Oral History Project. Columbia University Rare Books and Manuscript Library, 1970.

\section{Dwight D. Eisenhower Presidential Library}

Central Intelligence Agency. “The Iranian Situation.” Memorandum for the President of the United States. 1 March 1953. NSC Staff Papers, Box 65, Disaster File, Iran (3). Dwight D. Eisenhower Presidential Library.

Notes of Report Debriefing, Lt. General (Ret.) James H. Doolittle to Dwight D. Eisenhower. Meeting Notes. 19 October 1954. Ann Whitman File, Administration Series, Box 13. Dwight D. Eisenhower Presidential Library.

US National Security Council. 135 ${ }^{\text {th }}$ Meeting of the National Security Council, 4 March 1953. Ann Whitman Files, Box 4, NSC Series. Dwight D. Eisenhower Presidential Library.

The White House. "Panel of Consultants on Covert Activities of the Central Intelligence Agency.” Dwight D. Eisenhower to Lt. Gen. (Ret.) James H. Doolittle. Memorandum. 26 July 1954. Ann Whitman File, Administration Series, Box 13. Dwight D. Eisenhower Presidential Library. 


\section{Harry S. Truman Presidential Library}

Borel, Paul. "Mossadeq’s Demand for Emergency Aid.” Memorandum for the Director of Central Intelligence. 17 January 1952. President’s Secretary’s Files, Box 158, Harry S. Truman Presidential Library.

Central Intelligence Agency. “Analysis of the Iranian Political Situation.” Memorandum. 12 October 1951. Harry S. Truman Presidential Library. Accessed 21 July 2014. http://www.trumanlibrary.org.

Central Intelligence Agency. "Probable Developments in Iran in 1952 in the Absence of an Oil Settlement.” National Intelligence Estimate 46, February 4, 1952. President's Secretary Files, Truman Papers. Harry S. Truman Presidential Library. Accessed 1 October 2014. http://www.trumanlibrary.org

Central Intelligence Agency, “Probable Developments of Iran Through 1953.” National Intelligence Estimate 75, November 13, 1952. President's Secretary Files, Truman Papers. Harry S. Truman Presidential Library. Accessed 1 October 2014. http://www.trumanlibrary.org

Langer, William. “The Harriman Mission.” Memorandum for the Director of Central Intelligence. 3 August 1951. President’s Secretary’s Files, Box 158, Harry S. Truman Presidential Library.

US Department of State. “The Long Telegram.” George Kennan to George Marshall, February 22, 1946. Telegram. Harry S. Truman Administration File, Elsey Papers. Harry S. Truman Presidential Library. Accessed 30 September 2014. http://www.trumanlibrary.org/ whistlestop/study_collections/coldwar/documents/index.

US Department of State. Telegrams. President’s Secretary’s Files, Box 158, Harry S. Truman Presidential Library.

\section{The National Security Archive}

Central Intelligence Agency. The Battle for Iran. The National Security Archive. Accessed 1 August 2014. http://www2.gwu.edu/ nsarchiv/NSAEBB/NSAEBB435.

Central Intelligence Agency. “The Tudeh Party: Vehicle of Communism in Iran.” 18 July 1949. Digital National Security Archives. Proquest.

Koch, Scott A. “Zendebad, Shah!”: The Central Intelligence Agency and the Fall of Iranian Prime Minister Mohammed Mossadeq, August 1953. History Staff, Central Intelligence Agency, June 1998. Accessed 1 August 2014. http://www2.gwu.edu/ nsarchiv/ NSAEBB /NSAEBB435/.

US Department of State. "First Progress Report on Paragraph 5-1 of NSC 136/1, 'US Policy Regarding the Present Situation in Iran.'” 20 March 1953. National Archives and Records Administration (NARA), Record Group 59, Lot 63D351, National Security Council, Box 68. Accessed February 14, 2015. http://www2.gwu.edu/ nsarchiv/NSAEBB/ NSAEBB126/.

US National Security Council. “The Present Situation in Iran.” Statement of Policy 136/1, 20 November 1952. National Archives and Records Administration (NARA), Record Group 
59, Lot 63D351, National Security Council, Box 68. Accessed 14 February 2015. http://www2.gwu.edu/ nsarchiv/NSAEBB/NSAEBB126/.

\section{Memoirs and Primary Sources}

Acheson, Dean. Present at the Creation. New York, NY: Norton, 1969.

Albright, Madeleine K. "Remarks Before the American-Iranian Council.” 17 March 2000. Federation of American Scientists. Accessed 16 December 2014. http://www.fas.orgnews/ iran/2000/000317.htm.

Cline, Ray S. “Is Intelligence Over-Coordinated?” Studies of Intelligence 1, no. 4 (1957): 11-18. Accessed January 14, 2015. https://www.cia.gov/library/center-for-the-study-of-intelligence /kent-csi/vol1no4/html/v01i4a02p_0001.htm.

—. Secrets, Spies, and Scholars. Washington, DC: Acropolis Books, 1976.

Department of State. Foreign Relations of the United States, 1950, Vol. X. Washington, DC: Government Printing Office, 1978.

Dulles, Allen. The Craft of Intelligence. New York, NY: Harper \& Row, 1963.

Eisenhower, Dwight D. Mandate For Change, 1953-1956. Garden City, NY: Doubleday \& Co., 1963.

Kent, Sherman. “Estimates and Influence.” Studies of Intelligence 12, no. 3 (1968): 11-21. Accessed January 14, 2015. https://www.cia.gov/library/center-for-the-study-ofintelligence/kent-csi/vol12i3/html/v12i3a02p_0001.htm.

—. Strategic Intelligence for American World Policy. Princeton, NJ: Princeton University Press, 1949.

Langer, William L. In and Out of the Ivory Tower. New York, NY: N. Watson Academic Publications, 1977.

McGhee, George C. Envoy to the Middle World. New York, NY: Harper \& Row, 1983.

—. "Recollections of Dr. Muhammad Mussadiq," in Mussadiq, Iranian Nationalism, and Oil. Eds. James A. Bill and William Roger Louis. Austin, TX: University of Texas Press, 1988, 296-304.

Montague, Ludwell Lee. “The Origins of National Intelligence Estimating.” Studies of Intelligence 16, no. 2 (1972): 63-70. Accessed January 14, 2015. https://www.cia.gov/ library/center-for-the-study-of-intelligence/ken-csi.

Mosaddeq, Mohammad, and Homa Katouzian. Musaddiq's Memoirs. London, UK: JEBHE, National Movement of Iran, 1988.

Pahlavi, Mohammad Reza, Mission For My Country. New York, NY: McGraw-Hill, 1961.

Roosevelt, Kermit. Countercoup: The Struggle for the Control of Iran. New York, NY: McGrawHill, 1979. 
Truman, Harry S. Memoirs, II, Years of Trial and Hope, 1946-1952. Garden City, NY: Doubleday, 1956.

—. "The Truman Doctrine.” Address Delivered to a Joint Session of Congress, 12 March 1947. Accessed 30 September 2014. http://avalon.law.yale.edu/20th_century/ trudoc.asp.

Wisner, Frank. “On 'The Craft Of Intelligence.” Studies of Intelligence 8, no. 1 (1964): A1-A16. Accessed 14 January 2015. https://www.cia.gov/library/center-for-the-study-ofintelligence/kent-csi/vol8no1/html/v08i1a07p_0001.htm.

US National Security Council, “Iran.” Statement of Policy 107/2, 27 June 1951. Foreign Relations of the United States, 1952-1954, Vol X, 71-73.

Woodhouse, C. M. Something Ventured. London, UK: Granada, 1982.

\section{Secondary Source Materials}

Abrahamian, Ervand. A History of Modern Iran. Cambridge, UK: Cambridge University Press, 2008.

— The Coup. New York, NY: The New Press, 2013.

Albright, Madeleine Korbel, and William Woodward. Madam Secretary. New York, NY: Miramax Books, 2003.

Aldrich, Richard J, Rory Cormac, and Michael S Goodman. Spying on the World. Edinburgh, SCT: Edinburgh University Press, 2014.

Ambrose, Stephen E., and Richard H. Immerman. Ike's Spies: Eisenhower and the Espionage Establishment. Garden City, NY: Doubleday and Co., 1981.

Ameringer, Charles. US Foreign Intelligence: The Secret Side of American History. Lexington, MA: Lexington Books, 1990.

Balaghi, Shiva. "Silenced Histories and Sanitized Autobiographies: The 1953 CIA Coup in Iran.” Biography 36, no. 1 (Winter 2013): 71-96.

Bill, James A, and William Roger Louis. Mussadiq, Iranian Nationalism, and Oil. Austin, TX: University of Texas Press, 1988.

Blake, Kristen. The US-Soviet Confrontation in Iran, 1945-1962. Lanham, MD: University Press of America, 2009.

Bowie, Robert R, and Richard H Immerman. Waging Peace. New York, NY: Oxford University Press, 1998.

Brands, H. W. Cold Warriors: Eisenhower's Generation and American Foreign Policy. New York, NY: Columbia University Press, 1988.

Burleigh, Michael. Small Wars, Faraway Places. New York, NY: Penguin Group, 2013.

Byrne, Malcolm, and Mark J Gasiorowski. Mohammad Mosaddeq and the 1953 Coup in Iran. 
Syracuse, NY: Syracuse University Press, 2004.

Byrne, Malcolm. “Mohammad Mosaddeq and the 1953 Coup In Iran,” National Security Archive Electronic Briefing Book No. 126, June 22, 2004. Accessed 13 February 2015. http://www2.gwu.edu/ nsarchiv/NSAEBB/NSAEBB126/.

_ _ "CIA Confirms Role in 1953 Iran Coup,” National Security Archive Electronic Briefing Book No. 435, 19 August 2013. Accessed 1 September 2014. http://www2.gwu.edu/ nsarchiv/NSAEBB/NSAEBB435.

—. "The Secret CIA History of the Iran Coup, 1953,” National Security Archive Electronic Briefing Book No. 28, 29 November 2000. Accessed 1 September 2014. http://www2.gwu.edu/ nsarchiv/NSAEBB/NSAEBB28.

Cooper, Jeffrey. Curing Analytical Pathologies: Pathways to Improved Intelligence Analysis. Langley, VA: Central Intelligence Agency Center for the Study of Intelligence, 2005.

Davis, Jack. "Intelligence Analysts and Policymakers: Benefits and Dangers of Tensions in Relationship.” Intelligence and National Security 21, no. 6 (2006): 999-1021.

- Sherman Kent and the Profession of Intelligence Analysis. Washington, DC: Central Intelligence Agency Sherman Kent Center for Intelligence Analysts, 2002.

Debellaigue, Christopher. “Coupdunnit: What Really Happened in Iran?” Foreign Affairs (September/October 2014).

Duignan, Peter, and Alvin Rabushka. The United States In The 1980S. Stanford, CA: Hoover Institution, Stanford University, 1980.

Fisher, Rebecca and Rob Johnston. “Is Intelligence Analysis a Discipline?” Analyzing Intelligence: Origins, Obstacles and Innovations, eds. Roger Z. George and James B. Bruce (Washington, DC: Georgetown University Press, 2008), 55-70.

Gaddis, John Lewis. The United States and the Origins of the Cold War, 1941-1947. New York, NY: Columbia University Press, 1972.

—. Strategies of Containment. New York, NY: Oxford University Press, 1982.

Gasiorowski, Mark J. “The 1953 Coup d'Etat in Iran.” International Journal of Middle East Studies 19, no. 3 (August 1987): 261-86.

Gavin, Francis J. “Politics, Power, and US Policy In Iran, 1950-1953.” Journal of Cold War Studies 1, no. 1 (Winter 1999): 56-89.

Gentry, John A. Lost Promise: How CIA Analysis Misserves the Nation. Lanham, MD: University Press of America, 1993.

George, Roger Z., and James B. Bruce. Analyzing Intelligence. Washington, DC: Georgetown University, 2008.

Goodman, Michael S. The Official History of the Joint Intelligence Committee, Vol I: From the Approach of the Second World War to the Suez Crisis. Hoboken, NJ: Taylor and Francis, 2014. 
Grose, Peter. Gentleman Spy. Boston, MA: Houghton Mifflin, 1994.

Hersh, Burton. The Old Boys. New York, NY: Charles Scribner's Sons Macmillan Publishing Company, 1992.

Heuer, Richards J. Psychology of Intelligence Analysis. Washington, DC: Central Intelligence Agency Center for the Study of Intelligence, 1999.

Immerman, Richard. “Transforming Analysis: The Intelligence Community's Best Kept Secret.” Intelligence and National Security 26, no. 2-3 (2011): 159-181.

Janis, Irving L. Groupthink. Boston, MA: Houghton Mifflin, 1982.

Jervis, Robert. "Why Intelligence and Policymakers Clash.” Political Science Quarterly 125, no. 2 (2010): 185-204.

—. Why Intelligence Fails. Ithaca, NY: Cornell University Press, 2010.

Johnston, Rob. Analytic Culture in the US Intelligence Community. Washington, DC: Center for the Study of Intelligence, Central Intelligence Agency, 2005.

Jones, Milo, and Philippe Silberzahn. Constructing Cassandra. Stanford, CA: Stanford University Press, 2013.

Karabell, Zachary. Architects of Intervention: The United States, the Third World and the Cold War, 1946-1962. Baton Rouge, LA: Louisiana State University Press, 1999.

Katouzian, Homa. Musaddiq and the Struggle for Power in Iran. London, UK: I.B. Tauris, 1999.

Keddie, Nikki R, Yann Richard, and Nikki R Keddie. Modern Iran. New Haven, CT: Yale University Press, 2003.

Kinzer, Stephen. All the Shah's Men. Hoboken, NJ: J. Wiley \& Sons, 2003.

Koch, Scott A. “Zendebad, Shah!”: The Central Intelligence Agency and the Fall of Iranian Prime Minister Mohammed Mossadeq, August 1953. Central Intelligence Agency History, June 1998. Accessed 1 August 2014. http://www2.gwu.edu/ nsarchiv/ NSAEBB/ NSAEBB435/.

Kotter, John P. Power and Influence. New York, NY: Free Press, 1985.

Kuniholm, Bruce Robellet. The Origins of the Cold War in the Near East. Princeton, NJ: Princeton University Press, 1980.

Little, Douglas. "Mission Impossible: The CIA and the Cult of Covert Action in the Middle East.” Diplomatic History 28, no. 5 (2004): 663-701.

Mark, Edouard. “The War Scare of 1946 and its Consequences.” Diplomatic History 21, no. 3 (1997): 383-415.

Marsh, Steven. "Continuity and Change: Reinterpreting the Policies of the Truman and Eisenhower Administrations Toward Iran, 1950-1954.” Journal of Cold War Studies 7, no. 3 (2005): 79-123.

McMahon, Robert J. Dean Acheson and the Creation of an American World Order. Washington, 
DC: Potomac Books, 2009.

Mokhtari, Fariborz. “Iran's 1953 Coup Revisited: Internal Dynamics versus External Intrigue.” The Middle East Journal 62, no. 3 (2008): 457-488.

Montague, Ludwell Lee. General Walter Bedell Smith as Director of Central Intelligence, October 1950-February 1953. University Park, PA: Pennsylvania State University Press, 1992.

Osgood, Kenneth Alan. Total Cold War. Lawrence, KS: University of Kansas, 2006.

Parsa, Misagh. States, Ideologies, and Social Revolutions. Cambridge, UK: Cambridge University Press, 2000.

Ranelagh, John. The Agency: The Rise and Decline of The CIA. New York, NY: Simon and Schuster, 1986.

Robarge, David. “CIA and Covert Action.” Presentation. Fort Leavenworth, KS, 2014.

Rudgers, David F. Creating The Secret State. Lawrence, KS: University Press of Kansas, 2000.

Russell, Richard L. Sharpening Strategic Intelligence: Why the CIA Gets It Wrong, and What Needs to Be Done to Get It Right. New York, NY: Cambridge University Press, 2007.

Sicker, Martin. The Bear and the Lion. New York, NY: Praeger, 1988.

Smith, R. Harris. OSS. Berkeley, CA: University of California Press, 1972.

Srodes, James. Allen Dulles. Washington, DC: Regnery, 1999.

Takeyh, Ray. "What Really Happened in Iran: The CIA, the Ouster of Mosaddeq, and the Restoration of the Shah,” Foreign Affairs (July/August 2014).

Theoharis, Athan G. The Central Intelligence Agency: Security Under Scrutiny. Westport, CT: Greenwood Press, 2006.

Tinsley, Catherine H. "Social Categorization and Intergroup Dynamics.” Intelligence Analysis: Behavior and Social Scientific Foundations, ed. Fischhoff, Baruch, and Cherie Chauvin. (Washington, DC: National Academies Press, 2011).

Troy, Thomas F. Wild Bill and the Intrepid. New Haven, CT: Yale University Press, 1996.

Valero, Larry A. "The American Joint Intelligence Committee And Estimates of the Soviet Union, 1945-1947.” Studies in Intelligence Summer (2000): 65-80. Accessed 21 January 2015. https://www.cia.gov/library/center-for-the-study-of-intelligence/csi-publications/csistudies/studies/summer00/art06.html.

Wilford, Hugh. America's Great Game: The CIA's Secret Arabists and the Shaping of the Modern Middle East. New York, NY: Basic Books, 2013.

Wohlstetter, Roberta. Pearl Harbor; Warning and Decision. Stanford, CA: Stanford University Press, 1962.

Yergin, Daniel. The Prize. New York, NY: Simon \& Schuster, 1991. 
Zahrani, Mostafa T. "The Coup that Changed the Middle East: Mossadeq Vs. the CIA in Retrospect.” World Policy Journal 19, no. 2 (2002): 93-99.

Zegart, Amy B. Flawed by Design. Stanford, CA: Stanford University Press, 1999. 